\title{
Ostvarenje proračuna općina, gradova i županija u 2017. I
}

\author{
KATARINA OTT, MiHAELA BRONIĆ, BRANKO STANIĆ
}

Cilj je ovoga rada što jednostavnije, na temelju baze podataka Ministarstva financija, sistematizirati osnovne podatke o ostvarenju proračuna svih hrvatskih lokalnih jedinica ${ }^{2}$ za 20I7., prihodima i rashodima ${ }^{3}$ te suficitu ili deficitu (po stanovniku i ukupno). Dodani su i posljednji dostupni podatci o broju stanovnika i proračunskoj transparentnosti lokalnih jedinica. Uz pomoć ovoga teksta i tabela koje se nude i u Excel formatu, zainteresirani se mogu upoznati s financijskim stanjem svih općina, gradova i županija u 2017., te ih uspoređivati sa stanjem u prethodnim godinama. ${ }^{4}$

Ministarstvo financija već godinama redovito objavljuje ostvarenje proračuna svih lokalnih jedinica. ${ }^{5}$ Riječ je o brojnim i obimnim Excel tabelama u kojima su gradovi i općine složeni po županijama. Zbog velikog broja lokalnih jedinica i zbog složenosti proračuna, u njima se nije baš lako snalaziti i uspoređivati pojedine lokalne jedinice. Stoga je cilj ovoga rada omogućiti građanima brži i lakši uvid u njihovo osnovno financijsko stanje u 20I7., a podrobnije podatke mogu sami pronalaziti na mrežnim stranicama Ministarstva financija, ali i lokalnih jedinica, barem onih koje objavljuju svoje proračune. Za ispravno razumijevanje prikazanih podataka neophodno je, ipak, nekoliko napomena.

\section{S PODATCIMA OPREZNO}

Prvo, općine se mogu uspoređivati s općinama, gradovi s gradovima i županije sa županijama, ali ne može se uspoređivati podatke županija, gradova i općina. Županije, gradovi i općine su, naime, nadležni za prikupljanje

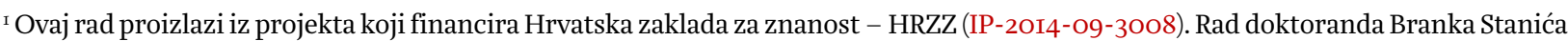
također financira HRZZ. Mišljenja, nalazi, zaključci i preporuke odnose se na autore i ne odražavaju nužno stajalište HRZZ-a.

${ }^{2}$ Bez obzira na službeno razlikovanje jedinica lokalne i područne (regionalne) samouprave, pojam "lokalne jedinice" u ovome tekstu podrazumijeva svih 20 županija, I28 gradova i 428 općina.

${ }^{3}$ Analiza obuhvaća samo prihode i rashode, bez primitaka i izdataka. Prihodi i rashodi se odnose na poslovanje te prodaju i nabavu nefinancijske imovine (npr. zemljišta, građevinskih objekata, koncesija, prijevoznih sredstava, itd.), a primitci i izdatci na financijsku imovinu, uzimanje, davanje i otplate zajmova. Detaljnije u Ott i sur. (2009).

4 Tabele $\mathrm{u}$ ovom tekstu nude podatke o financijskom stanju lokalnih jedinica u 20I7. i njihovoj proračunskoj transparentnosti iz 20I8., no tabela u Excelu sadrži i podatke o financijskom stanju u 20I4., 2015. i 20I6., te o proračunskoj transparentnosti iz 20I5., 20I6. i 20I7. Više informacija o prethodnim ostvarenjima proračuna hrvatskih lokalnih jedinica dostupno je u Ott i Bronić (2OI5) te Ott, Bronić i Stanić (20I6, 20I8), a o proračunskoj transparentnosti na poveznici. Podatci o broju stanovnika prema DZS-u (2OI8).

${ }_{5} \mathrm{Na}$ mrežnim stranicama Ministarstva financija/Lokalna samouprava/Financijski izvještaji JLP(R)S, dostupni su statistički izvještaji o izvršenju proračuna za razdoblje i995.-200I., nekonsolidirani financijski izvještaji - obrazac PR-RAS i RAS po funkcijskoj klasifikaciji za razdoblje 2002.-2017., te bilance za razdoblje 2002.-2017.
} 
različitih vrsta prihoda i pružanje različitih vrsta javnih dobara i usluga. Stoga prihodi i rashodi, kako ukupni, tako i po stanovniku, odražavaju i njihove različite nadležnosti (vidi grafikone I i 2). Zainteresirani mogu, primjerice, zbrojiti prihode ili rashode po stanovniku svoje općine ili grada i svoje županije i tako saznati koliko se ukupno na lokalnoj razini u prosjeku prikuplja i troši po stanovniku te općine ili grada. Iznimka je Zagreb - istovremeno i grad i županija - pa njegovi stanovnici trebaju gledati samo podatke za Zagreb.

Drugo, premda neke lokalne jedinice ostvaruju relativno visoke prihode po stanovniku, to ne mora značiti i da dobro posluju. Općina Civljane je, primjerice, 20I7. ostvarila najveće prihode po stanovniku (26.IO9 kn), a među vodećima, s prihodom većim od Io.ooo kn po stanovniku, nalaze se i općine Lokvičići, Lopar, Saborsko i Janjina. No, kod svih njih su velik dio prihoda poslovanja činile razne vrste pomoći, s udjelom u prihodima poslovanja od 30\% u Loparu, do čak 90\% u Lokvičićima. Slična je situacija i u nekim gradovima Vukovaru (gotovo 80\%), Ninu, Visu i Pazinu (oko 35\%) - s prihodima po stanovniku većim od 6.ooo kn.

Treće, sâm proračun lokalne jedinice ne mora uvijek odražavati njeno stvarno financijsko stanje, jer se može zaduživati i mimo proračuna, preko pravnih osoba čija je vlasnica/suvlasnica, te ustanovâ koje je osnovala. Stvarno financijsko stanje lokalnih jedinica moglo bi se prikazati samo ukoliko bi uz lokalni proračun bili dostupni i podatci o prihodima, rashodima, imovini, kapitalu i obvezama pravnih osoba u njihovu vlasništvu/suvlasništvu (npr. komunalna poduzeća) i ustanovâ koje su osnovale (npr. ustanove za upravljanje sportskim objektima). No, objedinjeni podatci o tim pravnim osobama i ustanovama nisu javno dostupni. Valja se nadati da će se usvajanjem i provedbom Akcijskog plana za provedbu inicijative Partnerstvo za otvorenu vlast u razdoblju od 20I8. do 2020., koji sadrži obvezu jačanja transparentnosti i odgovornosti na razini trgovačkih društava u većinskom vlasništvu lokalnih jedinica, bar djelomično popraviti uvid u stvarno financijsko stanje lokalnih jedinica.

Četvrto, premda u nekim lokalnim jedinicama postoje velike razlike između prihoda $\mathrm{i}$ rashoda $\mathrm{u}$ usporedbi s prethodnim godinama, to ne mora biti pokazatelj lošeg planiranja ili ostvarenja lokalnih proračuna. Moguće je da su lokalne jedinice baš u tom razdoblju ostvarile velike prodaje kapitalne imovine (npr. zemljišta ili zgrada), naplatile visoke iznose komunalne naknade, primile neuobičajeno velike pomoći iz inozemstva ili državnog proračuna, da su imale velika kapitalna ulaganja (npr. za lokalne ceste ili sportske objekte) koja su financirale kreditima i/ili pomoćima, da su prenijele viškove ili manjkove prihoda i primitaka iz prethodnih godina i sl. U 20I7. se, primjerice, općina Goričan zadužila za izgradnju sportske dvorane osnovne škole, općina Konjščina za dogradnju dječjeg vrtića, a općina Bosiljevo je investirala u asfaltiranje svojih nerazvrstanih cesta. Takvi i slični podatci - neophodni za bolje razumijevanje financijskog stanja lokalnih jedinica - ne mogu se baš uvijek pronaći na mrežnim stranicama Ministarstva financija, već je često potrebno pretražiti i mrežne stranice lokalnih jedinica i lokalnih medija. Ponekad je neophodno i kontaktirati izvršne ili zakonodavne vlasti lokalnih jedinica.

\section{SINTEZA PODATAKA I OSNOVNE ZANIMLJIVOSTI}

Premda cilj ovoga rada nije analizirati financijsko stanje lokalnih jedinica, nego tek ponuditi sintezu podataka iz baze Ministarstva financija za 20I7., ipak se mogu izdvojiti neke od uočenih zanimljivosti i naglasiti činjenice koje se ponavljaju iz godine u godinu.

\section{U razdoblju 20I4.-20I7. nije bilo većih oscilacija u prosječnim ukupnim i prosječnim prihodima po stanovniku lokalnih jedinica, tek je kod županija uočen porast prosječnih ukupnih prihoda, a kod općina porast prosječnih prihoda po stanovniku.}

U 20I7. najviši su prosječni ukupni prihodi županija (202 mil. kn), slijede ih gradovi sa Zagrebom (I23 mil. kn) i gradovi bez Zagreba (72 mil. kn), a na začelju su općine (9 mil. kn) (grafikon I). Po prosječnom prihodu po stanovniku, situacija se razlikuje, pa tako vode gradovi (sa Zagrebom $4.3 \mathrm{I} 4 \mathrm{kn}$, bez Zagreba $4.284 \mathrm{kn}$ ), slijede ih općine (3.863 kn), a na začelju su županije (I.319 kn) (grafikon 2). 
- Dvanaest je gradova i čak 33 općine ostvarilo prihode po stanovniku veće od Zagreba (8.177 kn).

- Čak dvije trećine općina, te više od 60\% gradova, imaju prihode po stanovniku manje od prosjeka općina, odnosno gradova.

- U razdoblju 20I4-2017. nije bilo većih oscilacija u odnosima prosjeka lokalnih jedinica, tek županije u 20I7. bilježe zamjetan porast prosječnih ukupnih prihoda u odnosu na prethodne godine (oko IO\%), a općine znatan porast prosječnih prihoda po stanovniku 20I7. u odnosu na 20I4. (više od 20\%).

- U istom su razdoblju općine u prosjeku imale vrlo uravnotežene proračune, gradovi bez Zagreba su uglavnom bili u blagom suficitu, dok su kod gradova sa Zagrebom i županija bile prilične oscilacije (grafikon 3).

\section{Grafikon I.}

Prosječni ukupni prihodi 20I4.-20I7. (u mil. kn)

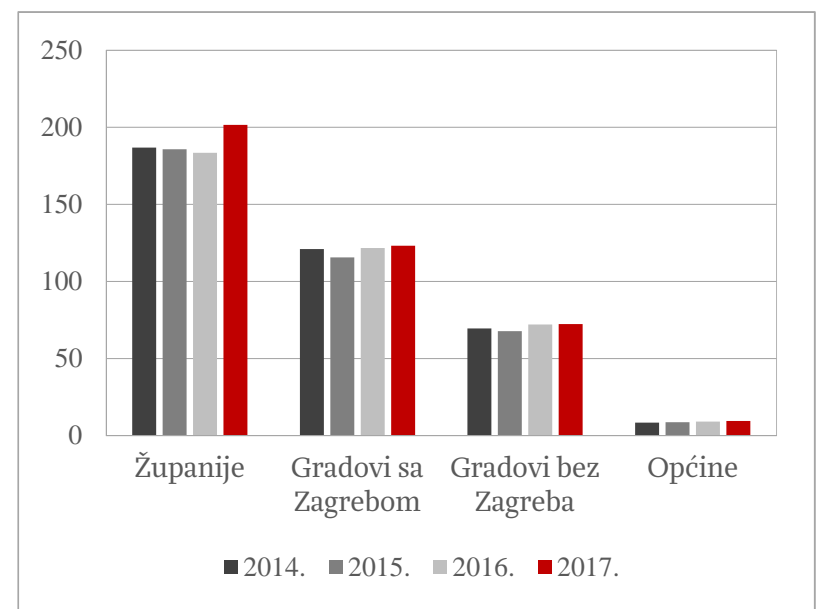

Izvor: Ministarstvo financija (2OI8)
Grafikon 2.

Prosječni prihodi po stanovniku* 20I4.-20I7. (u tis. kn)

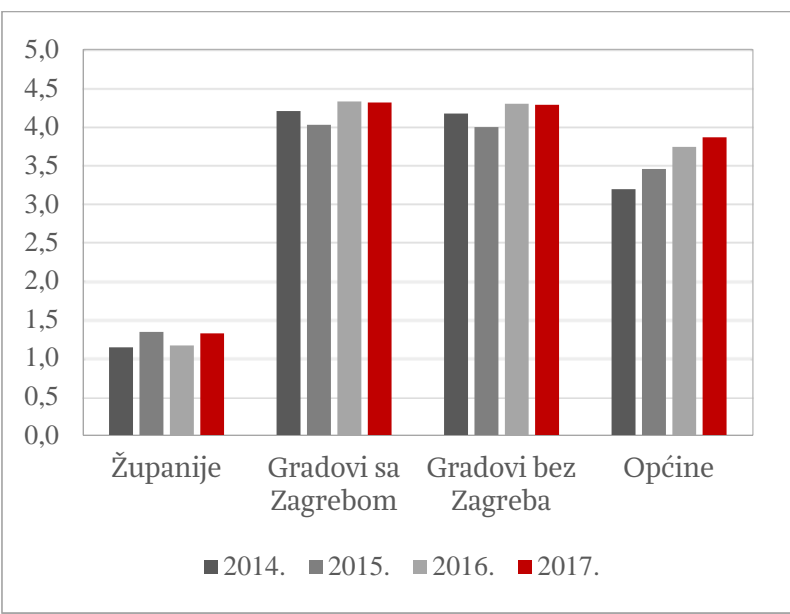

Izvor: Ministarstvo financija (20I8)

*Broj stanovnika prema DZS (2018)

\section{Grafikon 3.}

Prosječni ukupni suficit/deficit 2014.-2017. (u mil. kn)

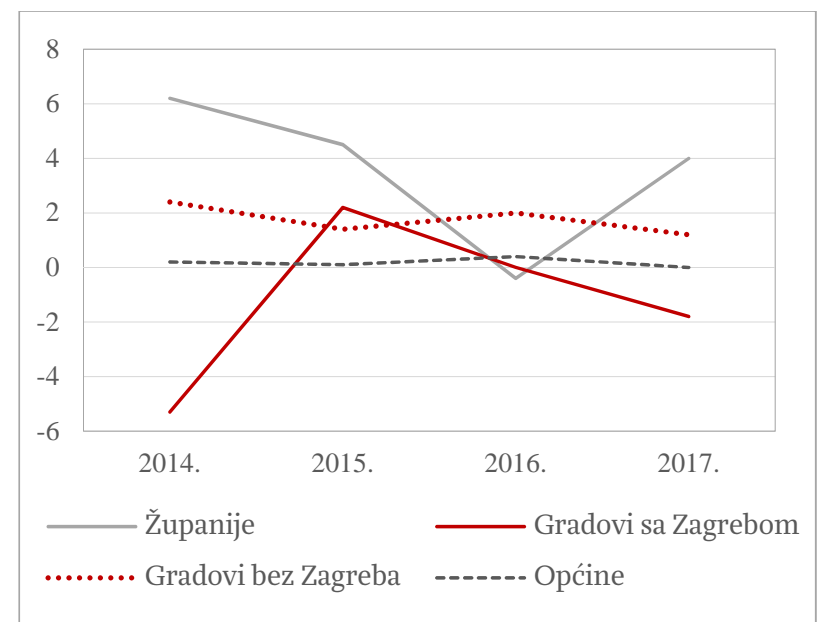

Izvor: Ministarstvo financija (2018) 


\section{Velike su razlike između najbogatijih i najsiromašnijih lokalnih jedinica.}

- Po prihodima po stanovniku s 26.Iog kn izrazito odskače općina Civljane, a slijede je općine Baška (I4.985 kn) i Karlobag (I4.785 kn).

- Najmanje prihode po stanovniku imaju općine Pojezerje (I.O35 kn), Maruševec (I.2OI kn) i Sveti Juraj na Bregu (r.303 kn).

- Kao i lani, po ukupnim prihodima vodeća je općina Medulin (80,3 mil. kn), a na začelju je Pojezerje (o,9 mil. kn).

- Iznos ukupnih prihoda samog Medulina jednak je zbroju ukupnih prihoda tridesetak općina s najnižim ukupnim prihodima.

- Prema prihodima po stanovniku, među gradovima vode Nin s I3.60I kn i Novalja s Io.623 kn, a na začelju su Lepoglava s I.548 kn, Novi Marof s I.647 kn i Donji Miholjac s I.7II kn.

- Izuzme li se grad Zagreb koji sa 6,57 mlrd. kn ostvaruje gotovo 42\% ukupnih prihoda svih gradova, po ukupnim su prihodima najjači Split sa 792 mil. kn i Rijeka sa 67I mil. kn. Na začelju su Komiža i Klanjec, oba sa 6,I mil. kn. Sâm Split ostvaruje ukupnih prihoda otprilike koliko 45 gradova s najnižim ukupnim prihodima zajedno.

\section{Presudan je utjecaj položaja uz more na financijsko stanje gradova i općina.}

- Od I9 općina s prihodom po stanovniku većim od Io.ooo kn samo Civljane, Lokvičići, Dugopolje i Saborsko nisu na moru. ${ }^{6}$

- Među više od dvije stotine općina s prihodom manjim od $2.800 \mathrm{kn}$ po stanovniku samo su dvije Vela Luka i Sukošan - na moru, a tek oko 7\% ih se nalazi u Jadranskoj Hrvatskoj. Među sedamdesetak općina s prihodom po stanovniku manjim od $2.000 \mathrm{kn}$, ni jedna nije na moru, a samo se jedna Pojezerje - nalazi u Jadranskoj Hrvatskoj.

- I gradovi s najviše prihoda po stanovniku - Nin i Novalja - nalaze se uz more, za razliku od gradova s najmanje prihoda po stanovniku (Lepoglava, Novi Marof i Donji Miholjac).

- Također, među prvih 25 gradova s prihodom višim od $6.000 \mathrm{kn}$ po stanovniku na moru nisu samo Zagreb, Obrovac, Vukovar i Pazin, dok su među šezdesetak gradova s prihodom po stanovniku nižim od 3.50o kn samo dva (Kaštela s 2.58I kn i Ploče s 3.468 kn) na moru.

- Trinaest općina s najvećim ukupnim prihodima - sve iznad 30 mil. kn - su u Jadranskoj Hrvatskoj.

\section{4. Česte su velike neusklađenosti između prihoda i rashoda pojedinih lokalnih jedinica unutar} jedne godine.

- Veliki je broj općina u kojima su ukupni rashodi znatno viši od prihoda, primjerice u Goričanu preko I50\%, Konjščini i Bosiljevu preko I2O\%, Gornjem Knegincu preko 90\%, Strahonincu i Pojezerju oko $70 \%$, Jalžabetu $55 \%$, Viru, Tkonu i Sračincu oko 50\%., itd. Kod gradova nema tako velikih odstupanja, no ističu se Orahovica sa 70\%, Labin s 35\% i Trilj s 30\% većim rashodima od prihoda.

- Brojne su i općine u kojima su ukupni prihodi znatno viši od rashoda, primjerice u Lekeniku 90\%, Privlaci (Zadar) 75\%, Vižinadi i Sikirevcima 70\%, itd. Kod gradova se ističu Opuzen s 90\%, Nin 76\%, Slunj $44 \%$, itd.

- Sve županije imaju izrazito uravnotežene prihode i rashode, s gotovo neznatnim razlikama između prihoda i rashoda.

\section{5. Česte su velike oscilacije prihoda i rashoda pojedinih lokalnih jedinica iz godine u godinu.}

- Premda iz godine u godinu nema drastičnih razlika u prosječnim prihodima po stanovniku županija, gradova i općina, pojedine su ih lokalne jedinice u 20I7. itekako povećale u odnosu na

\footnotetext{
${ }^{6}$ Premda se obično spominjani - po visokim prihodima po stanovniku i niskoj transparentnosti - Sutivan trgnuo i na mrežnim stranicama počeo objavljivati bar dio proračunskih dokumenata, i ove se godine među općinama s prihodima po stanovniku većim od Io.ooo kn nalaze i neke izrazito netransparentne. Primjerice, Lokvičići nisu objavili ni jedan, a Karlobag i Bol su objavili tek po jedan od traženih pet ključnih proračunskih dokumenata (vidi Ott, Bronić, Petrušić i Stanić, 20I8).
} 
prethodne godine. Među općinama vodi Biskupija koja ih je više nego utrostručila, pa Selca više nego udvostručila, te Polača i Slivno koje su ih gotovo udvostručile, a gradovi Opuzen i Nin su ih otprilike udvostručili. Kod županija nema tako drastičnih povećanja, no Ličko-senjska je prosječne prihode po stanovniku povećala za oko 6o\%, a Požeško-slavonska za oko 40\%.

6. Zbog neadekvatnih kriterija pri određivanju statusa općina i gradova, brojne su općine sa znatno većim ukupnim prihodima od ukupnih prihoda brojnih gradova, pa tako najbogatija općina (Medulin) ima 13 puta veće ukupne prihode od najsiromašnijeg grada (Komiže).

- $\quad$ Postoje, dakle, gradovi s manje od Io mil. kn ukupnih prihoda (Komiža, Klanjec, Hrvatska Kostajnica i Vrlika), ali i općine poput Medulina s više od 80 mil. kn i Matulja s više od 50 mil. kn.

\section{Isto tako, postoje i brojne općine sa znatno većim brojem stanovnika od brojnih gradova, pa najveća općina (Viškovo) ima II puta više stanovnika od najmanjeg grada (Komiže).}

- 42 su općine s više od 5.00o stanovnika, od čega ih je šest s više od Io.ooo stanovnika (Viškovo, Nedelišće, Matulji, Brdovec, Podstrana i Čepin), dok čak 64 grada imaju manje od Io.ooo stanovnika, od čega ih je 22 s manje od 5.0oo stanovnika, a najmanji su Komiža s I.50o i Vrlika s manje od I.9oo stanovnika.

- Ipak, čak 43 općine imaju manje od I.ooo stanovnika, a najmanje su Civljane sa I33, te Lanišće, Kijevo i Zadvarje sve s manje od 300 stanovnika. Još su i Ribnik, Lećevica, Saborsko i Sućuraj općine s manje od 500 stanovnika.

\section{PREPORUKE}

Kao što iz godine u godinu podatci ukazuju na manje-više iste obrasce ostvarenja proračuna županija, gradova i općina, te na manje-više iste probleme u praćenju tih ostvarenja, tako se iz godine u godinu mogu ponavljati i manje-više iste preporuke Vladi, Ministarstvu financija, lokalnim jedinicama, pa i samim građanima.

Ministarstvo financija na svojim mrežnim stranicama nudi proračune i bilance svih lokalnih jedinica, no za potpunije informiranje o ukupnom i stvarnom financijskom stanju lokalnih jedinica neophodno je učiniti sljedeće:

- Vlada - neovisno o novom Akcijskom planu za provedbu inicijative Partnerstvo za otvorenu vlast, pogotovo imajući u vidu slabu provedbu prethodnih akcijskih planova - mora odrediti nadležna ministarstva koja će za sve pravne osobe u vlasništvu i suvlasništvu lokalnih jedinica (bez obzira na postotak suvlasništva), kao i za ustanove koje su lokalne jedinice osnovale, objaviti jedinstvene, ažurne, strojno čitljive, online baze osnovnih podataka (popis s adresama i kontaktima) kao i njihovih bilanci te računa dobiti i gubitka.

- Ministarstvo financija - uz objavljene proračune i bilance svih lokalnih jedinica mora početi objavljivati pojašnjenja metodologije, obuhvata podataka i promjena u serijama podataka.

- Lokalne jedinice, njihovi proračunski i izvanproračunski korisnici moraju se pridržavati Zakona o proračunu i objavljivati godišnje financijske izvještaje koje ionako moraju predavati Fini. Bilo bi također dobro da se počnu pridržavati i uputa Ministarstva financija7 za izradu proračuna $u$ kojima im se preporučuje da sve materijale vezane uz proračun i njegove izmjene objavljuju u formatu pogodnom za daljnju obradu.

- Lokalne jedinice bi, također, morale na mrežnim stranicama u strojno čitljivom formatu objavljivati potpuna godišnja i polugodišnja izvješća o izvršenju proračuna (uključujući obrazloženja ostvarenja

\footnotetext{
> Dostupno na: http://www.mfin.hr/hr/upute-za-izradu-proracuna-jlprs-arhiva
} 
prihoda i primitaka te rashoda i izdataka) koja građanima olakšavaju razumijevanje proračuna. Bez narativnih objašnjenja, same brojke nisu dovoljne za razumijevanje proračuna.

- Sve baze podataka se moraju trajno i redovito ažurirati, a stare baze ne bi se smjele brisati.

U nadi da bi stanovnici lokalnih jedinica, njihove izvršne i predstavničke vlasti te lokalni mediji mogli biti zainteresirani za financijsko stanje svojih lokalnih jedinica i za usporedbu s drugim lokalnim jedinicama, uz ovaj se tekst nude i tabele u Excel formatu. Zainteresirani ih mogu preuzeti na svoja računala, te ih po želji i potrebi koristiti i preslagivati. ${ }^{8} \mathrm{Na}$ taj se način mogu podrobnije informirati i uključiti u analiziranje i odlučivanje o prikupljanju i trošenju lokalnih proračunskih sredstava. Usprkos brojnim manjkavostima u dostupnosti podataka, popriličan je broj lokalnih jedinica koje već nude mnoštvo informacija o svojim proračunima, uključujući proračunske vodiče, aplikacije, vizualizacije i strojno čitljive podatke. Stoga bi javnost trebala pokazati interes, proračunski se obrazovati i koristeći već dostupne podatke, te sudjelovati u proračunskim procesima.

Valja se također nadati da će ovi podatci - kao i niz drugih, objavljenih u prethodnim izdanjima Instituta za javne financije - zainteresirati i Vladu i nadležna ministarstva, Sabor i saborske odbore koji će se kadtad, ako već ne svojom voljom, onda zbog zahtjeva Europske komisije, morati suočiti s problemom „rascjepkanosti i funkcionalne raspodjele nadležnosti lokalnih jedinica” 9 i konačno reformirati teritorijalni i fiskalni ustroj države.

Tabela I.

Ostvarenje proračuna općina u 2017.

Po stanovniku, u kn

Ukupno, u mil. kn

\begin{tabular}{|c|c|c|c|c|c|c|c|c|}
\hline Općina & Prihodi & Rashodi & $\begin{array}{c}\text { Suficit } \\
\text { ili } \\
\text { deficit }\end{array}$ & $\begin{array}{c}\text { Broj } \\
\text { stanovni- } \\
\text { ka } 2016 .\end{array}$ & Prihodi & Rashodi & $\begin{array}{l}\text { Suficit } \\
\text { ili } \\
\text { deficit }\end{array}$ & $\begin{array}{c}\text { Transpa- } \\
\text { rentnost } \\
(0-5)\end{array}$ \\
\hline Civljane & 26.109 & 20.228 & 5.880 & 133 & 3,5 & 2,7 & 0,8 & 3 \\
\hline Baška & 14.985 & 14.252 & 734 & 1.740 & 26,1 & 24,8 & 1,3 & 5 \\
\hline Karlobag & 14.785 & 11.304 & 3.481 & 926 & 13,7 & 10,5 & 3,2 & 1 \\
\hline Funtana & 14.217 & 18.086 & -3.869 & 964 & 13,7 & 17,4 & $-3,7$ & 4 \\
\hline Sutivan & 13.795 & 12.769 & 1.026 & 914 & 12,6 & 11,7 & 0,9 & 2 \\
\hline Lokvičići & 13.418 & 13.517 & -100 & 619 & 8,3 & 8,4 & $-0,1$ & 0 \\
\hline Tar-Vabriga & 12.934 & 10.655 & 2.279 & 2.224 & 28,8 & 23,7 & 5,1 & 4 \\
\hline Dugopolje & 12.691 & 8.099 & 4.592 & 3.765 & 47,8 & 30,5 & 17,3 & 5 \\
\hline Lopar & 12.601 & 11.606 & 995 & 1.288 & 16,2 & 14,9 & 1,3 & 4 \\
\hline Vir & 12.287 & 18.723 & -6.436 & 3.749 & 46,1 & 70,2 & $-24,1$ & 3 \\
\hline Malinska-Dubašnica & 11.868 & 13.443 & -1.575 & 3.471 & 41,2 & 46,7 & $-5,5$ & 5 \\
\hline Medulin & 11.702 & 11.030 & 672 & 6.866 & 80,3 & 75,7 & 4,6 & 3 \\
\hline Kolan & 11.504 & 12.635 & -1.131 & 855 & 9,8 & 10,8 & $-1,0$ & 2 \\
\hline Punat & 10.914 & 9.539 & 1.375 & 2.010 & 21,9 & 19,2 & 2,8 & 4 \\
\hline Saborsko & 10.751 & 15.668 & -4.917 & 456 & 4,9 & 7,1 & $-2,2$ & 4 \\
\hline Bale & 10.722 & 8.936 & 1.786 & 1.141 & 12,2 & 10,2 & 2,0 & 4 \\
\hline Bol & 10.227 & 9.388 & 840 & 1.723 & 17,6 & 16,2 & 1,4 & 1 \\
\hline Kostrena & 10.152 & 10.367 & -215 & 4.421 & 44,9 & 45,8 & $-1,0$ & 5 \\
\hline Janjina & 10.006 & 9.806 & 200 & 551 & 5,5 & 5,4 & 0,1 & 3 \\
\hline Omišalj & 9.994 & 11.020 & -1.025 & 3.087 & 30,9 & 34,0 & $-3,2$ & 5 \\
\hline Kijevo & 9.841 & 9.043 & 798 & 291 & 2,9 & 2,6 & 0,2 & 2 \\
\hline Vrsar & 9.801 & 10.159 & -358 & 2.149 & 21,1 & 21,8 & $-0,8$ & 3 \\
\hline Biskupija & 9.711 & 6.626 & 3.084 & 1.172 & 11,4 & 7,8 & 3,6 & 3 \\
\hline Ervenik & 9.683 & 9.406 & 277 & 674 & 6,5 & 6,3 & 0,2 & 0 \\
\hline Kršan & 9.620 & 11.672 & -2.052 & 2.864 & 27,6 & 33,4 & $-5,9$ & 4 \\
\hline
\end{tabular}

${ }^{8}$ Tabele u Excel formatu s podatcima o lokalnim jedinicama nude se i u prethodnim tekstovima o ostvarenju lokalnih proračuna (Ott, Bronić i Stanić 20I8, 20I6; Ott i Bronić 20I5,) o proračunskoj transparentnosti (Ott i sur. 20I8, 2OI7), o korištenju EU fondova (Ott, Bronić i Stanić 20I8, 20I6), o zaduženosti (Ott i Bronić 2016).

9 Vidi Ott (2OI8). 
Po stanovniku, u kn

Ukupno, u mil. kn

\begin{tabular}{|c|c|c|c|c|c|c|c|c|}
\hline Općina & Prihodi & Rashodi & $\begin{array}{c}\text { Suficit } \\
\text { ili } \\
\text { deficit }\end{array}$ & $\begin{array}{c}\text { Broj } \\
\text { stanovni- } \\
\text { ka 2oI6. }\end{array}$ & Prihodi & Rashodi & $\begin{array}{c}\text { Suficit } \\
\text { ili } \\
\text { deficit }\end{array}$ & $\begin{array}{c}\text { Transpa- } \\
\text { rentnost } \\
(0-5)\end{array}$ \\
\hline Polača & 9.560 & 8.830 & 729 & 1.368 & 13,1 & 12,1 & 1,0 & 4 \\
\hline Vižinada & 9.349 & 5.484 & 3.865 & 1.168 & 10,9 & 6,4 & 4,5 & 4 \\
\hline Pićan & 9.046 & 7.565 & 1.481 & 1.766 & 16,0 & 13,4 & 2,6 & 4 \\
\hline Tučepi & 8.799 & 8.523 & 276 & 1.963 & 17,3 & 16,7 & 0,5 & 5 \\
\hline Zadvarje & 8.670 & 8.261 & 409 & 293 & 2,5 & 2,4 & 0,1 & 0 \\
\hline Fažana & 8.374 & 10.008 & -1.634 & 3.736 & 31,3 & 37,4 & $-6,1$ & 4 \\
\hline Šolta & 8.282 & 8.996 & -714 & 2.080 & 17,2 & 18,7 & $-1,5$ & 4 \\
\hline Rogoznica & 8.180 & 7.272 & 908 & 2.405 & 19,7 & 17,5 & 2,2 & 5 \\
\hline Baška Voda & 7.802 & 6.144 & 1.658 & 2.886 & 22,5 & 17,7 & 4,8 & 1 \\
\hline Lovas & 7.332 & 4.768 & 2.564 & 1.037 & 7,6 & 4,9 & 2,7 & 5 \\
\hline Mljet & 7.289 & 9.469 & -2.179 & 1.146 & 8,4 & 10,9 & $-2,5$ & 2 \\
\hline Dubrovačko Primorje & 7.269 & 8.590 & -1.321 & 1.794 & 13,0 & 15,4 & $-2,4$ & 3 \\
\hline Brela & 7.226 & 7.383 & -157 & 1.705 & 12,3 & 12,6 & $-0,3$ & 3 \\
\hline Povljana & 7.206 & 4.801 & 2.405 & 742 & 5,3 & 3,6 & 1,8 & 0 \\
\hline Grožnjan & 7.076 & 8.436 & -1.360 & 685 & 4,8 & 5,8 & $-0,9$ & 5 \\
\hline Lećevica & 7.034 & 9.098 & -2.063 & 449 & 3,2 & 4,1 & $-0,9$ & 4 \\
\hline Zagvozd & 7.034 & 6.151 & 882 & 988 & 6,9 & 6,1 & 0,9 & 2 \\
\hline Dobrinj & 6.984 & 6.526 & 458 & 2.301 & 16,1 & 15,0 & 1,1 & 4 \\
\hline Vrhovine & 6.977 & 5.812 & 1.164 & 1.088 & 7,6 & 6,3 & 1,3 & 3 \\
\hline Lovinac & 6.955 & 9.660 & -2.706 & 868 & 6,0 & 8,4 & $-2,3$ & 4 \\
\hline Privlaka (Zadar) & 6.941 & 3.964 & 2.977 & 2.258 & 15,7 & 8,9 & 6,7 & 4 \\
\hline Murter & 6.900 & 7.086 & -186 & 2.142 & 14,8 & 15,2 & $-0,4$ & 4 \\
\hline Ston & 6.879 & 7.170 & -291 & 2.290 & 15,8 & 16,4 & $-0,7$ & 3 \\
\hline Brtonigla & 6.833 & 7.198 & -366 & 1.615 & 11,0 & 11,6 & $-0,6$ & 5 \\
\hline Primošten & 6.755 & 7.156 & -401 & 2.826 & 19,1 & 20,2 & $-1,1$ & 5 \\
\hline Fužine & 6.719 & 6.125 & 594 & 1.456 & 9,8 & 8,9 & 0,9 & 4 \\
\hline Vrbnik & 6.698 & 7.605 & -907 & 1.228 & 8,2 & 9,3 & $-1,1$ & 4 \\
\hline Mošćenička Draga & 6.601 & 7.466 & -865 & 1.448 & 9,6 & 10,8 & $-1,3$ & 4 \\
\hline Selca & 6.492 & 6.348 & 143 & 1.780 & 11,6 & 11,3 & 0,3 & 5 \\
\hline Oprtalj & 6.448 & 5.987 & 461 & 791 & 5,1 & 4,7 & 0,4 & 2 \\
\hline Nerežišća & 6.360 & 5.545 & 815 & 887 & 5,6 & 4,9 & 0,7 & 1 \\
\hline Prgomet & 6.323 & 5.123 & 1.201 & 572 & 3,6 & 2,9 & 0,7 & 0 \\
\hline Jelsa & 6.245 & 6.092 & 153 & 3.697 & 23,1 & 22,5 & 0,6 & 3 \\
\hline Lovran & 6.219 & 5.387 & 832 & 3.925 & 24,4 & 21,1 & 3,3 & 5 \\
\hline Tkon & 6.105 & 9.166 & -3.061 & 796 & 4,9 & 7,3 & $-2,4$ & 5 \\
\hline Promina & 6.010 & 6.276 & -266 & 1.007 & 6,1 & 6,3 & $-0,3$ & 5 \\
\hline Tribunj & 6.004 & 4.861 & 1.143 & 1.621 & 9,7 & 7,9 & 1,9 & 5 \\
\hline Tisno & 5.952 & 8.297 & -2.345 & 3.144 & 18,7 & 26,1 & $-7,4$ & 4 \\
\hline Plitvička Jezera & 5.917 & 5.562 & 356 & 3.725 & 22,0 & 20,7 & 1,3 & 3 \\
\hline Trpanj & 5.883 & 4.646 & 1.237 & 725 & 4,3 & 3,4 & 0,9 & 4 \\
\hline Sali & 5.866 & 6.146 & -280 & 1.879 & 11,0 & 11,5 & $-0,5$ & 3 \\
\hline Okrug & 5.853 & 5.352 & 501 & 3.557 & 20,8 & 19,0 & 1,8 & 4 \\
\hline Sućuraj & 5.830 & 6.660 & -830 & 490 & 2,9 & 3,3 & $-0,4$ & 0 \\
\hline Podgora & 5.824 & 5.614 & 210 & 2.492 & 14,5 & 14,0 & 0,5 & 5 \\
\hline Konavle & 5.781 & 6.317 & -536 & 8.386 & 48,5 & 53,0 & $-4,5$ & 5 \\
\hline Milna & 5.712 & 5.023 & 688 & 1.149 & 6,6 & 5,8 & 0,8 & 0 \\
\hline Postira & 5.699 & 5.468 & 231 & 1.587 & 9,0 & 8,7 & 0,4 & 2 \\
\hline Starigrad & 5.691 & 5.787 & -97 & 1.915 & 10,9 & 11,1 & $-0,2$ & 5 \\
\hline Slivno & 5.365 & 3.722 & 1.643 & 1.860 & 10,0 & 6,9 & 3,1 & 1 \\
\hline Smokvica & 5.354 & 3.858 & 1.496 & 887 & 4,7 & 3,4 & 1,3 & 2 \\
\hline Kalinovac & 5.342 & 4.054 & 1.288 & 1.420 & 7,6 & 5,8 & 1,8 & 5 \\
\hline Vuka & 5.299 & 4.811 & 488 & 1.058 & 5,6 & 5,1 & 0,5 & 5 \\
\hline Župa Dubrovačka & 5.201 & 5.433 & -232 & 8.855 & 46,1 & 48,1 & $-2,1$ & 3 \\
\hline Jasenovac & 5.198 & 4.178 & 1.020 & 1.754 & 9,1 & 7,3 & 1,8 & 4 \\
\hline Skrad & 5.155 & 4.564 & 591 & 920 & 4,7 & 4,2 & 0,5 & 4 \\
\hline Kukljica & 5.111 & 4.029 & 1.081 & 755 & 3,9 & 3,0 & 0,8 & 3 \\
\hline Orebić & 5.106 & 4.956 & 150 & 4.200 & 21,4 & 20,8 & 0,6 & 4 \\
\hline
\end{tabular}

NEWSLETTER II6 | K. OTT i sur. | Ostvarenje proračuna općina, gradova i županija u 20I7. | Institut za javne financije 7 
Po stanovniku, u kn

Ukupno, u mil. kn

\begin{tabular}{|c|c|c|c|c|c|c|c|c|}
\hline Općina & Prihodi & Rashodi & $\begin{array}{c}\text { Suficit } \\
\text { ili } \\
\text { deficit }\end{array}$ & $\begin{array}{c}\text { Broj } \\
\text { stanovni- } \\
\text { ka 2oI6. }\end{array}$ & Prihodi & Rashodi & $\begin{array}{c}\text { Suficit } \\
\text { ili } \\
\text { deficit }\end{array}$ & $\begin{array}{c}\text { Transpa- } \\
\text { rentnost } \\
(0-5)\end{array}$ \\
\hline Lišane Ostrovičke & 5.100 & 5.394 & -294 & 594 & 3,0 & 3,2 & $-0,2$ & 4 \\
\hline Vrsi & 5.046 & 4.367 & 679 & 2.074 & 10,5 & 9,1 & 1,4 & 2 \\
\hline Pirovac & 5.041 & 5.191 & -151 & 1.942 & 9,8 & 10,1 & $-0,3$ & 4 \\
\hline Pašman & 5.024 & 5.363 & -340 & 2.258 & 11,3 & 12,1 & $-0,8$ & 1 \\
\hline Marčana & 5.010 & 5.052 & -42 & 4.434 & 22,2 & 22,4 & $-0,2$ & 4 \\
\hline Primorski Dolac & 5.008 & 4.733 & 275 & 724 & 3,6 & 3,4 & 0,2 & 4 \\
\hline Jasenice & 4.997 & 5.541 & -544 & 1.391 & 7,0 & 7,7 & $-0,8$ & 4 \\
\hline Čeminac & 4.947 & 5.816 & -870 & 2.704 & 13,4 & 15,7 & $-2,4$ & 0 \\
\hline Mrkopalj & 4.901 & 4.887 & 14 & 1.013 & 5,0 & 5,0 & 0,0 & 3 \\
\hline Kanfanar & 4.876 & 5.363 & -487 & 1.572 & 7,7 & 8,4 & $-0,8$ & 4 \\
\hline Lastovo & 4.873 & 5.109 & -237 & 776 & 3,8 & 4,0 & $-0,2$ & 3 \\
\hline Zemunik Donji & 4.830 & 3.519 & 1.310 & 1.954 & 9,4 & 6,9 & 2,6 & 3 \\
\hline Rakovica & 4.816 & 4.803 & 13 & 2.220 & 10,7 & 10,7 & 0,0 & 3 \\
\hline Vinodolska općina & 4.807 & 4.438 & 368 & 3.400 & 16,3 & 15,1 & 1,3 & 2 \\
\hline Ribnik & 4.794 & 5.553 & -758 & 400 & 1,9 & 2,2 & $-0,3$ & 5 \\
\hline Preko & 4.792 & 4.760 & 32 & 4.047 & 19,4 & 19,3 & 0,1 & 0 \\
\hline Popovac & 4.712 & 4.141 & 572 & 1.650 & 7,8 & 6,8 & 0,9 & 3 \\
\hline Višnjan & 4.684 & 4.468 & 217 & 2.297 & 10,8 & 10,3 & 0,5 & 1 \\
\hline Udbina & 4.662 & 5.186 & -524 & 1.490 & 6,9 & 7,7 & $-0,8$ & 5 \\
\hline Motovun & 4.661 & 4.522 & 138 & 1.031 & 4,8 & 4,7 & 0,1 & 2 \\
\hline Stara Gradiška & 4.650 & 3.905 & 745 & 1.015 & 4,7 & 4,0 & 0,8 & 5 \\
\hline Magadenovac & 4.622 & 4.733 & -111 & 1.813 & 8,4 & 8,6 & $-0,2$ & 3 \\
\hline Matulji & 4.532 & 4.115 & 418 & 11.315 & 51,3 & 46,6 & 4,7 & 5 \\
\hline Kaštelir - Labinci & 4.502 & 4.009 & 493 & 1.498 & 6,7 & 6,0 & 0,7 & 1 \\
\hline Gračac & 4.497 & 4.171 & 326 & 3.486 & 15,7 & 14,5 & 1,1 & 5 \\
\hline Žumberak & 4.485 & 3.961 & 524 & 690 & 3,1 & 2,7 & 0,4 & 2 \\
\hline Sveti Filip i Jakov & 4.458 & 4.262 & 196 & 4.643 & 20,7 & 19,8 & 0,9 & 3 \\
\hline Stupnik & 4.454 & 3.750 & 704 & 3.925 & 17,5 & 14,7 & 2,8 & 4 \\
\hline Perušić & 4.451 & 4.889 & -439 & 2.186 & 9,7 & 10,7 & $-1,0$ & 5 \\
\hline Tovarnik & 4.403 & 3.725 & 679 & 2.278 & 10,0 & 8,5 & 1,5 & 4 \\
\hline Lokve & 4.378 & 4.483 & -105 & 943 & 4,1 & 4,2 & $-0,1$ & 3 \\
\hline Novigrad & 4.375 & 3.897 & 478 & 2.191 & 9,6 & 8,5 & 1,0 & 3 \\
\hline Lanišće & 4.366 & 5.070 & -704 & 273 & 1,2 & 1,4 & $-0,2$ & 4 \\
\hline Raša & 4.360 & 4.896 & -536 & 2.988 & 13,0 & 14,6 & $-1,6$ & 4 \\
\hline Brod Moravice & 4.346 & 3.862 & 484 & 773 & 3,4 & 3,0 & 0,4 & 4 \\
\hline Svetvinčenat & 4.323 & 4.290 & 33 & 2.252 & 9,7 & 9,7 & 0,1 & 5 \\
\hline Kali & 4.319 & 4.265 & 54 & 1.645 & 7,1 & 7,0 & 0,1 & 4 \\
\hline Kneževi Vinogradi & 4.309 & 4.912 & -603 & 4.033 & 17,4 & 19,8 & $-2,4$ & 5 \\
\hline Čavle & 4.269 & 3.618 & 651 & 7.368 & 31,5 & 26,7 & 4,8 & 5 \\
\hline Darda & 4.245 & 3.404 & 841 & 6.383 & 27,1 & 21,7 & 5,4 & 1 \\
\hline Lovreć & 4.238 & 3.325 & 913 & 1.429 & 6,1 & 4,8 & 1,3 & 0 \\
\hline Gola & 4.216 & 3.899 & 318 & 2.224 & 9,4 & 8,7 & 0,7 & 5 \\
\hline Sirač & 4.203 & 3.744 & 459 & 1.956 & 8,2 & 7,3 & 0,9 & 4 \\
\hline Drnje & 4.148 & 3.858 & 290 & 1.751 & 7,3 & 6,8 & 0,5 & 5 \\
\hline Tompojevci & 4.133 & 2.528 & 1.605 & 1.265 & 5,2 & 3,2 & 2,0 & 5 \\
\hline Gradac & 4.126 & 3.935 & 192 & 3.034 & 12,5 & 11,9 & 0,6 & 2 \\
\hline Donji Lapac & 4.086 & 3.284 & 802 & 1.625 & 6,6 & 5,3 & 1,3 & 1 \\
\hline Pakoštane & 4.085 & 4.178 & -93 & 4.186 & 17,1 & 17,5 & $-0,4$ & 3 \\
\hline Klis & 4.073 & 4.585 & -512 & 5.067 & 20,6 & 23,2 & $-2,6$ & 1 \\
\hline Lumbarda & 4.071 & 4.349 & -278 & 1.244 & 5,1 & 5,4 & $-0,3$ & 3 \\
\hline Klana & 4.049 & 3.537 & 512 & 1.887 & 7,6 & 6,7 & 1,0 & 4 \\
\hline Marina & 4.045 & 4.112 & -67 & 4.674 & 18,9 & 19,2 & $-0,3$ & 1 \\
\hline Kamanje & 4.032 & 4.274 & -242 & 828 & 3,3 & 3,5 & $-0,2$ & 5 \\
\hline Molve & 4.018 & 3.859 & 160 & 1.988 & 8,0 & 7,7 & 0,3 & 4 \\
\hline Šestanovac & 3.982 & 3.310 & 671 & 1.771 & 7,1 & 5,9 & 1,2 & 1 \\
\hline Blato & 3.955 & 3.592 & 363 & 3.601 & 14,2 & 12,9 & 1,3 & 3 \\
\hline Sveti Lovreč & 3.954 & 4.791 & -838 & 1.053 & 4,2 & 5,0 & $-0,9$ & 3 \\
\hline
\end{tabular}


Po stanovniku, u kn

Ukupno, u mil. kn

\begin{tabular}{|c|c|c|c|c|c|c|c|c|}
\hline Općina & Prihodi & Rashodi & $\begin{array}{c}\text { Suficit } \\
\text { ili } \\
\text { deficit }\end{array}$ & $\begin{array}{c}\text { Broj } \\
\text { stanovni- } \\
\text { ka 2oI6. }\end{array}$ & Prihodi & Rashodi & $\begin{array}{c}\text { Suficit } \\
\text { ili } \\
\text { deficit }\end{array}$ & $\begin{array}{c}\text { Transpa- } \\
\text { rentnost } \\
(0-5)\end{array}$ \\
\hline Seget & 3.948 & 4.746 & -798 & 4.735 & 18,7 & 22,5 & $-3,8$ & 0 \\
\hline Pučišća & 3.933 & 3.514 & 419 & 2.126 & 8,4 & 7,5 & 0,9 & 3 \\
\hline Koprivnički Ivanec & 3.898 & 3.633 & 265 & 2.006 & 7,8 & 7,3 & 0,5 & 4 \\
\hline Crnac & 3.876 & 3.489 & 387 & 1.212 & 4,7 & 4,2 & 0,5 & 5 \\
\hline Tinjan & 3.871 & 4.344 & -473 & 1.682 & 6,5 & 7,3 & $-0,8$ & 1 \\
\hline Sopje & 3.866 & 3.363 & 504 & 2.120 & 8,2 & 7,1 & 1,1 & 1 \\
\hline Virje & 3.855 & 3.828 & 27 & 4.225 & 16,3 & 16,2 & 0,1 & 4 \\
\hline Pokupsko & 3.851 & 3.708 & 143 & 2.095 & 8,1 & 7,8 & 0,3 & 4 \\
\hline Pisarovina & 3.832 & 4.068 & -235 & 3.589 & 13,8 & 14,6 & $-0,8$ & 5 \\
\hline Gračišće & 3.807 & 3.674 & 133 & 1.400 & 5,3 & 5,1 & 0,2 & 5 \\
\hline Draž & 3.803 & 3.638 & 165 & 2.308 & 8,8 & 8,4 & 0,4 & 3 \\
\hline Zmijavci & 3.790 & 3.541 & 250 & 1.878 & 7,1 & 6,6 & 0,5 & 0 \\
\hline Donji Kukuruzari & 3.770 & 2.885 & 886 & 1.271 & 4,8 & 3,7 & 1,1 & 3 \\
\hline Rakovec & 3.765 & 3.028 & 737 & 1.190 & 4,5 & 3,6 & 0,9 & 4 \\
\hline Bibinje & 3.750 & 2.589 & 1.161 & 4.144 & 15,5 & 10,7 & 4,8 & 4 \\
\hline Nova Bukovica & 3.739 & 3.216 & 523 & 1.504 & 5,6 & 4,8 & 0,8 & 3 \\
\hline Ližnjan & 3.733 & 3.578 & 155 & 4.452 & 16,6 & 15,9 & 0,7 & 4 \\
\hline Sveta Nedelja & 3.711 & 4.034 & -323 & 2.964 & 11,0 & 12,0 & $-1,0$ & 4 \\
\hline Vrbanja & 3.699 & 3.210 & 489 & 3.476 & 12,9 & 11,2 & 1,7 & 3 \\
\hline Hrvace & 3.696 & 3.465 & 231 & 3.077 & 11,4 & 10,7 & 0,7 & 1 \\
\hline Krnjak & 3.662 & 3.130 & 532 & 1.558 & 5,7 & 4,9 & 0,8 & 3 \\
\hline Podstrana & 3.636 & 4.047 & -411 & 11.122 & 40,4 & 45,0 & $-4,6$ & 2 \\
\hline Lekenik & 3.604 & 1.891 & 1.713 & 5.842 & 21,1 & 11,0 & 10,0 & 2 \\
\hline Nijemci & 3.594 & 3.775 & -181 & 3.953 & 14,2 & 14,9 & $-0,7$ & 5 \\
\hline Stari Jankovci & 3.538 & 2.567 & 971 & 3.778 & 13,4 & 9,7 & 3,7 & 5 \\
\hline Lasinja & 3.530 & 3.402 & 128 & 1.418 & 5,0 & 4,8 & 0,2 & 5 \\
\hline Lupoglav & 3.504 & 4.162 & -658 & 887 & 3,1 & 3,7 & $-0,6$ & 3 \\
\hline Tounj & 3.495 & 3.214 & 281 & 1.058 & 3,7 & 3,4 & 0,3 & 5 \\
\hline Gorjani & 3.488 & 3.059 & 429 & 1.495 & 5,2 & 4,6 & 0,6 & 0 \\
\hline Severin & 3.446 & 2.982 & 464 & 804 & 2,8 & 2,4 & 0,4 & 3 \\
\hline Ravna Gora & 3.438 & 3.394 & 44 & 2.208 & 7,6 & 7,5 & 0,1 & 3 \\
\hline Voćin & 3.437 & 3.762 & -325 & 2.199 & 7,6 & 8,3 & $-0,7$ & 3 \\
\hline Bosiljevo & 3.436 & 7.594 & -4.158 & 1.152 & 4,0 & 8,7 & $-4,8$ & 3 \\
\hline Majur & 3.433 & 3.835 & -402 & 927 & 3,2 & 3,6 & $-0,4$ & 1 \\
\hline Petlovac & 3.398 & 3.316 & 82 & 2.123 & 7,2 & 7,0 & 0,2 & 4 \\
\hline Ljubešćica & 3.390 & 3.807 & -417 & 1.734 & 5,9 & 6,6 & $-0,7$ & 3 \\
\hline Cista Provo & 3.380 & 2.917 & 463 & 1.938 & 6,6 & 5,7 & 0,9 & 1 \\
\hline Vladislavci & 3.376 & 3.125 & 251 & 1.692 & 5,7 & 5,3 & 0,4 & 5 \\
\hline Kula Norinska & 3.300 & 2.176 & 1.124 & 1.620 & 5,3 & 3,5 & 1,8 & 3 \\
\hline Marija Gorica & 3.295 & 2.917 & 379 & 2.203 & 7,3 & 6,4 & 0,8 & 5 \\
\hline Vinica & 3.288 & 3.437 & -149 & 3.201 & 10,5 & 11,0 & $-0,5$ & 2 \\
\hline Cetingrad & 3.286 & 3.578 & -292 & 1.557 & 5,1 & 5,6 & $-0,5$ & 2 \\
\hline Jagodnjak & 3.271 & 3.564 & -293 & 1.809 & 5,9 & 6,4 & $-0,5$ & 3 \\
\hline Unešić & 3.265 & 3.062 & 203 & 1.347 & 4,4 & 4,1 & 0,3 & 3 \\
\hline Štrigova & 3.238 & 2.981 & 257 & 2.626 & 8,5 & 7,8 & 0,7 & 5 \\
\hline Poličnik & 3.232 & 2.937 & 295 & 4.551 & 14,7 & 13,4 & 1,3 & 3 \\
\hline Barilović & 3.232 & 3.263 & -31 & 2.807 & 9,1 & 9,2 & $-0,1$ & 5 \\
\hline Antunovac & 3.232 & 3.272 & -40 & 3.664 & 11,8 & 12,0 & $-0,1$ & 4 \\
\hline Pušća & 3.185 & 3.123 & 62 & 2.758 & 8,8 & 8,6 & 0,2 & 3 \\
\hline Podravska Moslavina & 3.181 & 2.401 & 780 & 1.069 & 3,4 & 2,6 & 0,8 & 0 \\
\hline Satnica Đakovačka & 3.176 & 2.593 & 582 & 2.012 & 6,4 & 5,2 & 1,2 & 3 \\
\hline Brinje & 3.163 & 2.988 & 176 & 2.844 & 9,0 & 8,5 & 0,5 & 3 \\
\hline Barban & 3.161 & 3.010 & 150 & 2.599 & 8,2 & 7,8 & 0,4 & 5 \\
\hline Šandrovac & 3.154 & 3.165 & -11 & 1.556 & 4,9 & 4,9 & 0,0 & 3 \\
\hline Semeljci & 3.135 & 2.058 & 1.077 & 4.084 & 12,8 & 8,4 & 4,4 & 3 \\
\hline Kalnik & 3.084 & 3.077 & 7 & 1.256 & 3,9 & 3,9 & 0,0 & 4 \\
\hline Zagorska Sela & 3.068 & 2.755 & 313 & 905 & 2,8 & 2,5 & 0,3 & 1 \\
\hline
\end{tabular}

NEWSLETTER II6 | K. OTT i sur. | Ostvarenje proračuna općina, gradova i županija u 20I7. | Institut za javne financije 9 
Po stanovniku, u kn

Ukupno, u mil. kn

\begin{tabular}{|c|c|c|c|c|c|c|c|c|}
\hline Općina & Prihodi & Rashodi & $\begin{array}{c}\text { Suficit } \\
\text { ili } \\
\text { deficit }\end{array}$ & $\begin{array}{c}\text { Broj } \\
\text { stanovni- } \\
\text { ka } 2016 .\end{array}$ & Prihodi & Rashodi & $\begin{array}{c}\text { Suficit } \\
\text { ili } \\
\text { deficit }\end{array}$ & $\begin{array}{c}\text { Transpa- } \\
\text { rentnost } \\
(0-5)\end{array}$ \\
\hline Feričanci & 3.052 & 3.227 & -175 & 1.981 & 6,0 & 6,4 & $-0,3$ & 3 \\
\hline Ružić & 3.047 & 2.424 & 623 & 1.427 & 4,3 & 3,5 & 0,9 & 5 \\
\hline Josipdol & 3.043 & 3.346 & -302 & 3.568 & 10,9 & 11,9 & $-1,1$ & 5 \\
\hline Šodolovci & 3.031 & 2.985 & 46 & 1.398 & 4,2 & 4,2 & 0,1 & 5 \\
\hline Levanjska Varoš & 3.030 & 3.336 & -306 & 1.058 & 3,2 & 3,5 & $-0,3$ & 2 \\
\hline Cerovlje & 3.006 & 2.840 & 167 & 1.566 & 4,7 & 4,4 & 0,3 & 4 \\
\hline Stankovci & 2.999 & 3.704 & -704 & 1.911 & 5,7 & 7,1 & $-1,3$ & 0 \\
\hline Bistra & 2.990 & 3.137 & -147 & 6.534 & 19,5 & 20,5 & $-1,0$ & 5 \\
\hline Legrad & 2.988 & 2.747 & 242 & 1.984 & 5,9 & 5,4 & 0,5 & 4 \\
\hline Stubičke Toplice & 2.978 & 2.854 & 124 & 2.744 & 8,2 & 7,8 & 0,3 & 5 \\
\hline Lipovljani & 2.965 & 2.572 & 393 & 3.245 & 9,6 & 8,3 & 1,3 & 4 \\
\hline Berek & 2.955 & 3.357 & -402 & 1.315 & 3,9 & 4,4 & $-0,5$ & 4 \\
\hline Ražanac & 2.946 & 3.332 & -386 & 3.018 & 8,9 & 10,1 & $-1,2$ & 3 \\
\hline Topusko & 2.946 & 2.592 & 354 & 2.560 & 7,5 & 6,6 & 0,9 & 4 \\
\hline Kistanje & 2.942 & 2.945 & -3 & 2.760 & 8,1 & 8,1 & 0,0 & 5 \\
\hline Bilje & 2.928 & 3.186 & -258 & 5.239 & 15,3 & 16,7 & $-1,4$ & 3 \\
\hline Žakanje & 2.924 & 2.657 & 267 & 1.809 & 5,3 & 4,8 & 0,5 & 4 \\
\hline Punitovci & 2.898 & 3.012 & -114 & 1.699 & 4,9 & 5,1 & $-0,2$ & 0 \\
\hline Zdenci & 2.895 & 3.012 & -117 & 1.677 & 4,9 & 5,1 & $-0,2$ & 3 \\
\hline Posedarje & 2.880 & 2.808 & 71 & 3.641 & 10,5 & 10,2 & 0,3 & 5 \\
\hline Drenovci & 2.879 & 2.938 & -59 & 4.542 & 13,1 & 13,3 & $-0,3$ & 3 \\
\hline Čađavica & 2.873 & 2.964 & -91 & 1.777 & 5,1 & 5,3 & $-0,2$ & 3 \\
\hline Novi Golubovec & 2.854 & 2.671 & 184 & 949 & 2,7 & 2,5 & 0,2 & 1 \\
\hline Žminj & 2.840 & 2.984 & -144 & 3.450 & 9,8 & 10,3 & $-0,5$ & 4 \\
\hline Kotoriba & 2.838 & 2.746 & 92 & 3.172 & 9,0 & 8,7 & 0,3 & 3 \\
\hline Muć & 2.836 & 2.803 & 33 & 3.660 & 10,4 & 10,3 & 0,1 & 4 \\
\hline Velika Trnovitica & 2.823 & 2.797 & 25 & 1.270 & 3,6 & 3,6 & 0,0 & 4 \\
\hline Podravske Sesvete & 2.812 & 2.275 & 537 & 1.578 & 4,4 & 3,6 & 0,8 & 5 \\
\hline Dugi Rat & 2.801 & 3.008 & -207 & 7.055 & 19,8 & 21,2 & $-1,5$ & 4 \\
\hline Sukošan & 2.797 & 2.852 & -55 & 4.860 & 13,6 & 13,9 & $-0,3$ & 5 \\
\hline Plaški & 2.790 & 2.987 & -196 & 1.796 & 5,0 & 5,4 & $-0,4$ & 3 \\
\hline Ernestinovo & 2.790 & 2.589 & 201 & 2.035 & 5,7 & 5,3 & 0,4 & 3 \\
\hline Veliki Grđevac & 2.789 & 2.307 & 482 & 2.551 & 7,1 & 5,9 & 1,2 & 3 \\
\hline Luka & 2.781 & 3.428 & -646 & 1.354 & 3,8 & 4,6 & $-0,9$ & 4 \\
\hline Hum na Sutli & 2.778 & 2.807 & -29 & 4.675 & 13,0 & 13,1 & $-0,1$ & 3 \\
\hline Križ & 2.772 & 3.125 & -354 & 6.531 & 18,1 & 20,4 & $-2,3$ & 5 \\
\hline Podbablje & 2.752 & 2.210 & 542 & 4.346 & 12,0 & 9,6 & 2,4 & 0 \\
\hline Viljevo & 2.745 & 2.430 & 315 & 1.895 & 5,2 & 4,6 & 0,6 & 2 \\
\hline Gornji Kneginec & 2.732 & 5.228 & -2.496 & 5.190 & 14,2 & 27,1 & $-13,0$ & 3 \\
\hline Mihovljan & 2.727 & 2.763 & -36 & 1.797 & 4,9 & 5,0 & $-0,1$ & 2 \\
\hline Oriovac & 2.724 & 3.074 & -351 & 5.328 & 14,5 & 16,4 & $-1,9$ & 4 \\
\hline Hercegovac & 2.720 & 2.286 & 434 & 2.099 & 5,7 & 4,8 & 0,9 & 5 \\
\hline Petrijevci & 2.715 & 2.376 & 339 & 2.759 & 7,5 & 6,6 & 0,9 & 4 \\
\hline Zrinski Topolovac & 2.700 & 2.368 & 332 & 819 & 2,2 & 1,9 & 0,3 & 0 \\
\hline Gornji Mihaljevec & 2.678 & 2.392 & 286 & 1.819 & 4,9 & 4,4 & 0,5 & 0 \\
\hline Petrovsko & 2.671 & 3.079 & -408 & 2.490 & 6,7 & 7,7 & $-1,0$ & 3 \\
\hline Tordinci & 2.670 & 2.607 & 63 & 1.759 & 4,7 & 4,6 & 0,1 & 1 \\
\hline Marija Bistrica & 2.657 & 2.725 & -68 & 5.710 & 15,2 & 15,6 & $-0,4$ & 4 \\
\hline Lukač & 2.646 & 2.272 & 374 & 3.198 & 8,5 & 7,3 & 1,2 & 5 \\
\hline Dragalić & 2.642 & 2.087 & 554 & 1.163 & 3,1 & 2,4 & 0,6 & 3 \\
\hline Hlebine & 2.639 & 2.575 & 63 & 1.262 & 3,3 & 3,3 & 0,1 & 5 \\
\hline Viškovo & 2.618 & 2.887 & -269 & 16.331 & 42,7 & 47,1 & $-4,4$ & 5 \\
\hline Proložac & 2.613 & 2.246 & 367 & 3.318 & 8,7 & 7,5 & 1,2 & 0 \\
\hline Bogdanovci & 2.551 & 2.371 & 180 & 1.750 & 4,5 & 4,1 & 0,3 & 2 \\
\hline Runovići & 2.546 & 2.049 & 497 & 2.192 & 5,6 & 4,5 & 1,1 & 1 \\
\hline Veliko Trojstvo & 2.542 & 2.443 & 98 & 2.514 & 6,4 & 6,1 & 0,2 & 5 \\
\hline Novo Virje & 2.541 & 2.099 & 442 & 1.122 & 2,9 & 2,4 & 0,5 & 3 \\
\hline
\end{tabular}

IO NEWSLETTER II6 | K. OTT i sur. | Ostvarenje proračuna općina, gradova i županija u 2017. | Institut za javne financije 
Po stanovniku, u kn

Ukupno, u mil. kn

\begin{tabular}{|c|c|c|c|c|c|c|c|c|}
\hline Općina & Prihodi & Rashodi & $\begin{array}{c}\text { Suficit } \\
\text { ili } \\
\text { deficit }\end{array}$ & $\begin{array}{c}\text { Broj } \\
\text { stanovni- } \\
\text { ka 2oI6. }\end{array}$ & Prihodi & Rashodi & $\begin{array}{c}\text { Suficit } \\
\text { ili } \\
\text { deficit }\end{array}$ & $\begin{array}{c}\text { Transpa- } \\
\text { rentnost } \\
(0-5)\end{array}$ \\
\hline Sveti Petar u Šumi & 2.532 & 2.631 & -99 & 1.038 & 2,6 & 2,7 & $-0,1$ & 1 \\
\hline Dubravica & 2.527 & 3.086 & -559 & 1.350 & 3,4 & 4,2 & $-0,8$ & 5 \\
\hline Čačinci & 2.523 & 2.910 & -388 & 2.447 & 6,2 & 7,1 & $-0,9$ & 5 \\
\hline Velika Pisanica & 2.514 & 2.468 & 46 & 1.539 & 3,9 & 3,8 & 0,1 & 5 \\
\hline Mikleuš & 2.512 & 2.501 & 11 & 1.298 & 3,3 & 3,2 & 0,0 & 5 \\
\hline Breznica & 2.501 & 3.148 & -648 & 2.096 & 5,2 & 6,6 & $-1,4$ & 1 \\
\hline Klakar & 2.498 & 2.421 & 77 & 2.196 & 5,5 & 5,3 & 0,2 & 3 \\
\hline Brdovec & 2.493 & 2.633 & -139 & 11.280 & 28,1 & 29,7 & $-1,6$ & 4 \\
\hline Marijanci & 2.476 & 2.276 & 200 & 2.209 & 5,5 & 5,0 & 0,4 & 2 \\
\hline Đulovac & 2.475 & 2.640 & -165 & 2.942 & 7,3 & 7,8 & $-0,5$ & 5 \\
\hline Oprisavci & 2.470 & 2.139 & 330 & 2.282 & 5,6 & 4,9 & 0,8 & 4 \\
\hline Gvozd & 2.467 & 2.253 & 214 & 2.173 & 5,4 & 4,9 & 0,5 & 3 \\
\hline Štefanje & 2.466 & 2.353 & 113 & 1.812 & 4,5 & 4,3 & 0,2 & 3 \\
\hline Bilice & 2.462 & 2.066 & 396 & 2.492 & 6,1 & 5,1 & 1,0 & 2 \\
\hline Otok & 2.453 & 2.182 & 270 & 5.218 & 12,8 & 11,4 & 1,4 & 1 \\
\hline Vojnić & 2.428 & 2.550 & -122 & 4.065 & 9,9 & 10,4 & $-0,5$ & 5 \\
\hline Sunja & 2.425 & 2.625 & -200 & 4.650 & 11,3 & 12,2 & $-0,9$ & 4 \\
\hline Vela Luka & 2.416 & 2.335 & 81 & 4.024 & 9,7 & 9,4 & 0,3 & 5 \\
\hline Bizovac & 2.416 & 2.628 & -211 & 4.221 & 10,2 & 11,1 & $-0,9$ & 3 \\
\hline Hrvatska Dubica & 2.412 & 2.119 & 293 & 1.693 & 4,1 & 3,6 & 0,5 & 3 \\
\hline Zažablje & 2.410 & 2.202 & 207 & 628 & 1,5 & 1,4 & 0,1 & 3 \\
\hline Gradina & 2.409 & 1.563 & 846 & 3.273 & 7,9 & 5,1 & 2,8 & 3 \\
\hline Erdut & 2.404 & 2.998 & -594 & 6.329 & 15,2 & 19,0 & $-3,8$ & 3 \\
\hline Velika Ludina & 2.372 & 3.271 & -899 & 2.520 & 6,0 & 8,2 & $-2,3$ & 4 \\
\hline Visoko & 2.368 & 2.431 & -63 & 1.438 & 3,4 & 3,5 & $-0,1$ & 2 \\
\hline Bošnjaci & 2.356 & 2.138 & 219 & 3.447 & 8,1 & 7,4 & 0,8 & 1 \\
\hline Zlatar Bistrica & 2.347 & 2.022 & 325 & 2.441 & 5,7 & 4,9 & 0,8 & 4 \\
\hline Peteranec & 2.344 & 1.975 & 369 & 2.605 & 6,1 & 5,1 & 1,0 & 5 \\
\hline Jelenje & 2.339 & 2.037 & 302 & 5.433 & 12,7 & 11,1 & 1,6 & 5 \\
\hline Martijanec & 2.329 & 1.937 & 392 & 2.872 & 6,7 & 5,6 & 1,1 & 3 \\
\hline Klinča Sela & 2.322 & 2.370 & -48 & 5.217 & 12,1 & 12,4 & $-0,2$ & 4 \\
\hline Belica & 2.311 & 2.111 & 200 & 3.024 & 7,0 & 6,4 & 0,6 & 5 \\
\hline Cestica & 2.311 & 2.443 & -132 & 5.709 & 13,2 & 13,9 & $-0,8$ & 3 \\
\hline Generalski Stol & 2.304 & 2.272 & 32 & 2.342 & 5,4 & 5,3 & 0,1 & 4 \\
\hline Dicmo & 2.304 & 2.082 & 222 & 2.889 & 6,7 & 6,0 & 0,6 & 0 \\
\hline Brodski Stupnik & 2.304 & 2.536 & -232 & 2.698 & 6,2 & 6,8 & $-0,6$ & 4 \\
\hline Nova Kapela & 2.284 & 2.085 & 199 & 3.775 & 8,6 & 7,9 & 0,8 & 3 \\
\hline Špišić Bukovica & 2.280 & 1.990 & 290 & 3.849 & 8,8 & 7,7 & 1,1 & 4 \\
\hline Gornji Bogićevci & 2.277 & 2.074 & 203 & 1.736 & 4,0 & 3,6 & 0,4 & 3 \\
\hline Bedenica & 2.275 & 2.385 & -110 & 1.335 & 3,0 & 3,2 & $-0,1$ & 0 \\
\hline Radoboj & 2.265 & 2.239 & 26 & 3.148 & 7,1 & 7,0 & 0,1 & 4 \\
\hline Kapela & 2.259 & 1.996 & 263 & 2.741 & 6,2 & 5,5 & 0,7 & 3 \\
\hline Rugvica & 2.250 & 2.477 & -227 & 7.817 & 17,6 & 19,4 & $-1,8$ & 5 \\
\hline Podgorač & 2.239 & 2.578 & -338 & 2.669 & 6,0 & 6,9 & $-0,9$ & 3 \\
\hline Viškovci & 2.239 & 2.330 & -90 & 1.729 & 3,9 & 4,0 & $-0,2$ & 1 \\
\hline Krapinske Toplice & 2.238 & 2.301 & -64 & 5.122 & 11,5 & 11,8 & $-0,3$ & 4 \\
\hline Jesenje & 2.235 & 2.306 & -72 & 1.458 & 3,3 & 3,4 & $-0,1$ & 3 \\
\hline Desinić & 2.231 & 2.349 & -118 & 2.629 & 5,9 & 6,2 & $-0,3$ & 4 \\
\hline Nova Rača & 2.224 & 1.986 & 238 & 3.072 & 6,8 & 6,1 & 0,7 & 2 \\
\hline Trnava & 2.215 & 2.394 & -179 & 1.450 & 3,2 & 3,5 & $-0,3$ & 1 \\
\hline Gunja & 2.207 & 1.986 & 222 & 3.285 & 7,3 & 6,5 & 0,7 & 1 \\
\hline Končanica & 2.205 & 2.402 & -196 & 2.110 & 4,7 & 5,1 & $-0,4$ & 3 \\
\hline Dekanovec & 2.204 & 2.431 & -227 & 741 & 1,6 & 1,8 & $-0,2$ & 5 \\
\hline Privlaka (Vinkovci) & 2.198 & 2.276 & -79 & 2.620 & 5,8 & 6,0 & $-0,2$ & 1 \\
\hline Preseka & 2.191 & 2.109 & 82 & 1.307 & 2,9 & 2,8 & 0,1 & 4 \\
\hline Škabrnja & 2.183 & 2.537 & -353 & 1.718 & 3,8 & 4,4 & $-0,6$ & 2 \\
\hline Okučani & 2.182 & 1.999 & 183 & 2.784 & 6,1 & 5,6 & 0,5 & 1 \\
\hline
\end{tabular}

NEWSLETTER Ii6 | K. OTT i sur. | Ostvarenje proračuna općina, gradova i županija u 2017. | Institut za javne financije II 
Po stanovniku, u kn

Ukupno, u mil. kn

\begin{tabular}{|c|c|c|c|c|c|c|c|c|}
\hline Općina & Prihodi & Rashodi & $\begin{array}{c}\text { Suficit } \\
\text { ili } \\
\text { deficit }\end{array}$ & $\begin{array}{c}\text { Broj } \\
\text { stanovni- } \\
\text { ka } 2016 .\end{array}$ & Prihodi & Rashodi & $\begin{array}{c}\text { Suficit } \\
\text { ili } \\
\text { deficit }\end{array}$ & $\begin{array}{c}\text { Transpa- } \\
\text { rentnost } \\
(0-5)\end{array}$ \\
\hline Gundinci & 2.180 & 2.902 & -722 & 1.886 & 4,1 & 5,5 & $-1,4$ & 3 \\
\hline Domašinec & 2.167 & 1.579 & 588 & 2.132 & 4,6 & 3,4 & 1,3 & 2 \\
\hline Koška & 2.163 & 2.042 & 122 & 3.671 & 7,9 & 7,5 & 0,4 & 5 \\
\hline Pitomača & 2.157 & 1.908 & 249 & 9.598 & 20,7 & 18,3 & 2,4 & 5 \\
\hline Karojba & 2.157 & 2.429 & -272 & 1.401 & 3,0 & 3,4 & $-0,4$ & 3 \\
\hline Cerna & 2.154 & 2.132 & 22 & 4.282 & 9,2 & 9,1 & 0,1 & 5 \\
\hline Markušica & 2.150 & 1.710 & 440 & 2.232 & 4,8 & 3,8 & 1,0 & 2 \\
\hline Selnica & 2.145 & 2.186 & -41 & 2.915 & 6,3 & 6,4 & $-0,1$ & 5 \\
\hline Veliko Trgovišće & 2.142 & 2.184 & -42 & 4.813 & 10,3 & 10,5 & $-0,2$ & 4 \\
\hline Veliki Bukovec & 2.141 & 1.816 & 325 & 1.354 & 2,9 & 2,5 & 0,4 & 3 \\
\hline Budinščina & 2.136 & 2.242 & -106 & 2.326 & 5,0 & 5,2 & $-0,2$ & 3 \\
\hline Andrijaševci & 2.136 & 1.933 & 203 & 3.984 & 8,5 & 7,7 & 0,8 & 5 \\
\hline Jakšić & 2.129 & 1.606 & 524 & 3.749 & 8,0 & 6,0 & 2,0 & 4 \\
\hline Ferdinandovac & 2.120 & 1.716 & 404 & 1.569 & 3,3 & 2,7 & 0,6 & 5 \\
\hline Vođinci & 2.116 & 2.284 & -168 & 1.873 & 4,0 & 4,3 & $-0,3$ & 3 \\
\hline Dvor & 2.114 & 2.059 & 54 & 4.019 & 8,5 & 8,3 & 0,2 & 4 \\
\hline Kloštar Ivanić & 2.111 & 2.996 & -885 & 5.917 & 12,5 & 17,7 & $-5,2$ & 5 \\
\hline Staro Petrovo Selo & 2.107 & 1.705 & 402 & 4.625 & 9,7 & 7,9 & 1,9 & 3 \\
\hline Novigrad Podravski & 2.103 & 1.850 & 253 & 2.642 & 5,6 & 4,9 & 0,7 & 4 \\
\hline Mala Subotica & 2.102 & 2.787 & -685 & 4.606 & 9,7 & 12,8 & $-3,2$ & 5 \\
\hline Vrpolje & 2.099 & 2.249 & -150 & 3.188 & 6,7 & 7,2 & $-0,5$ & 5 \\
\hline Tuhelj & 2.091 & 1.876 & 215 & 2.042 & 4,3 & 3,8 & 0,4 & 3 \\
\hline Donja Motičina & 2.085 & 2.371 & -286 & 1.510 & 3,1 & 3,6 & $-0,4$ & 1 \\
\hline Suhopolje & 2.084 & 2.172 & -88 & 5.990 & 12,5 & 13,0 & $-0,5$ & 4 \\
\hline Podcrkavlje & 2.073 & 2.431 & -359 & 2.439 & 5,1 & 5,9 & $-0,9$ & 2 \\
\hline Farkaševac & 2.065 & 1.987 & 77 & 1.774 & 3,7 & 3,5 & 0,1 & 4 \\
\hline Podturen & 2.063 & 1.716 & 348 & 3.652 & 7,5 & 6,3 & 1,3 & 4 \\
\hline Pribislavec & 2.062 & 1.958 & 103 & 3.174 & 6,5 & 6,2 & 0,3 & 4 \\
\hline Hrašćina & 2.057 & 2.124 & -66 & 1.463 & 3,0 & 3,1 & $-0,1$ & 3 \\
\hline Orle & 2.056 & 1.788 & 268 & 1.919 & 3,9 & 3,4 & 0,5 & 3 \\
\hline Drenje & 2.056 & 2.290 & -233 & 2.414 & 5,0 & 5,5 & $-0,6$ & 0 \\
\hline Brestovac & 2.050 & 2.259 & -210 & 3.286 & 6,7 & 7,4 & $-0,7$ & 4 \\
\hline Đelekovec & 2.049 & 2.615 & -566 & 1.413 & 2,9 & 3,7 & $-0,8$ & 5 \\
\hline Orehovica & 2.049 & 1.678 & 370 & 2.833 & 5,8 & 4,8 & 1,0 & 4 \\
\hline Gornja Stubica & 2.045 & 2.167 & -121 & 4.954 & 10,1 & 10,7 & $-0,6$ & 4 \\
\hline Donja Voća & 2.043 & 2.301 & -258 & 2.174 & 4,4 & 5,0 & $-0,6$ & 1 \\
\hline Netretić & 2.041 & 1.720 & 321 & 2.627 & 5,4 & 4,5 & 0,8 & 5 \\
\hline Martinska Ves & 2.041 & 2.072 & -31 & 3.206 & 6,5 & 6,6 & $-0,1$ & 2 \\
\hline Ivankovo & 2.040 & 2.518 & -478 & 7.425 & 15,1 & 18,7 & $-3,6$ & 3 \\
\hline Galovac & 2.038 & 1.660 & 378 & 1.244 & 2,5 & 2,1 & 0,5 & 3 \\
\hline Gradište & 2.027 & 1.853 & 174 & 2.477 & 5,0 & 4,6 & 0,4 & 1 \\
\hline Đurđenovac & 2.021 & 2.594 & -573 & 6.075 & 12,3 & 15,8 & $-3,5$ & 2 \\
\hline Davor & 2.011 & 2.003 & 7 & 2.835 & 5,7 & 5,7 & 0,0 & 1 \\
\hline Donji Kraljevec & 2.002 & 1.792 & 210 & 4.372 & 8,8 & 7,8 & 0,9 & 3 \\
\hline Cernik & 2.002 & 2.039 & -38 & 3.222 & 6,4 & 6,6 & $-0,1$ & 5 \\
\hline Jalžabet & 1.999 & 3.106 & -1.106 & 3.728 & 7,5 & 11,6 & $-4,1$ & 2 \\
\hline Garčin & 1.996 & 1.914 & 82 & 4.419 & 8,8 & 8,5 & 0,4 & 3 \\
\hline Brckovljani & 1.991 & 2.221 & -230 & 6.576 & 13,1 & 14,6 & $-1,5$ & 3 \\
\hline Mali Bukovec & 1.985 & 1.936 & 49 & 2.052 & 4,1 & 4,0 & 0,1 & 4 \\
\hline Bednja & 1.984 & 1.705 & 280 & 3.606 & 7,2 & 6,1 & 1,0 & 4 \\
\hline Đurmanec & 1.976 & 2.144 & -167 & 3.978 & 7,9 & 8,5 & $-0,7$ & 4 \\
\hline Konjščina & 1.974 & 4.396 & -2.422 & 3.548 & 7,0 & 15,6 & $-8,6$ & 4 \\
\hline Kloštar Podravski & 1.969 & 2.023 & -54 & 3.152 & 6,2 & 6,4 & $-0,2$ & 3 \\
\hline Strahoninec & 1.968 & 3.337 & -1.369 & 2.631 & 5,2 & 8,8 & $-3,6$ & 5 \\
\hline Dežanovac & 1.965 & 1.926 & 38 & 2.296 & 4,5 & 4,4 & 0,1 & 3 \\
\hline Kravarsko & 1.964 & 2.147 & -182 & 1.941 & 3,8 & 4,2 & $-0,4$ & 5 \\
\hline Donji Andrijevci & 1.960 & 2.035 & -74 & 3.406 & 6,7 & 6,9 & $-0,3$ & 3 \\
\hline
\end{tabular}

I2 NEWSLETTER II6 | K. OTT i sur. | Ostvarenje proračuna općina, gradova i županija u 20I7. | Institut za javne financije 
Po stanovniku, u kn

Ukupno, u mil. kn

\begin{tabular}{|c|c|c|c|c|c|c|c|c|}
\hline Općina & Prihodi & Rashodi & $\begin{array}{c}\text { Suficit } \\
\text { ili } \\
\text { deficit }\end{array}$ & $\begin{array}{c}\text { Broj } \\
\text { stanovni- } \\
\text { ka } 2016 .\end{array}$ & Prihodi & Rashodi & $\begin{array}{c}\text { Suficit } \\
\text { ili } \\
\text { deficit }\end{array}$ & $\begin{array}{c}\text { Transpa- } \\
\text { rentnost } \\
(0-5)\end{array}$ \\
\hline Čaglin & 1.960 & 1.775 & 185 & 2.603 & 5,1 & 4,6 & 0,5 & 5 \\
\hline Gornja Vrba & 1.950 & 1.682 & 268 & 2.396 & 4,7 & 4,0 & 0,6 & 5 \\
\hline Gornja Rijeka & 1.945 & 2.076 & -130 & 1.659 & 3,2 & 3,4 & $-0,2$ & 5 \\
\hline Donja Dubrava & 1.945 & 2.098 & -153 & 1.771 & 3,4 & 3,7 & $-0,3$ & 3 \\
\hline Jakovlje & 1.941 & 1.828 & 112 & 3.801 & 7,4 & 6,9 & 0,4 & 4 \\
\hline Nuštar & 1.936 & 1.967 & -31 & 5.432 & 10,5 & 10,7 & $-0,2$ & 2 \\
\hline Velika Kopanica & 1.936 & 1.636 & 299 & 2.952 & 5,7 & 4,8 & 0,9 & 3 \\
\hline Strizivojna & 1.934 & 1.803 & 131 & 2.363 & 4,6 & 4,3 & 0,3 & 2 \\
\hline Jarmina & 1.929 & 2.057 & -127 & 2.323 & 4,5 & 4,8 & $-0,3$ & 5 \\
\hline Gradec & 1.899 & 2.063 & -164 & 3.480 & 6,6 & 7,2 & $-0,6$ & 3 \\
\hline Sveti Ilija & 1.897 & 1.962 & -65 & 3.468 & 6,6 & 6,8 & $-0,2$ & 5 \\
\hline Stari Mikanovci & 1.895 & 1.973 & -78 & 2.699 & 5,1 & 5,3 & $-0,2$ & 3 \\
\hline Šenkovec & 1.889 & 2.680 & -790 & 2.904 & 5,5 & 7,8 & $-2,3$ & 4 \\
\hline Negoslavci & 1.882 & 1.659 & 224 & 1.286 & 2,4 & 2,1 & 0,3 & 1 \\
\hline Lobor & 1.855 & 1.961 & -105 & 3.105 & 5,8 & 6,1 & $-0,3$ & 4 \\
\hline Kaptol & 1.852 & 1.869 & -18 & 3.022 & 5,6 & 5,6 & $-0,1$ & 4 \\
\hline Vrbje & 1.844 & 1.732 & 112 & 1.933 & 3,6 & 3,3 & 0,2 & 1 \\
\hline Rovišće & 1.842 & 2.284 & -442 & 4.494 & 8,3 & 10,3 & $-2,0$ & 5 \\
\hline Sibinj & 1.828 & 2.038 & -210 & 6.433 & 11,8 & 13,1 & $-1,4$ & 5 \\
\hline Koprivnički Bregi & 1.819 & 1.709 & 110 & 2.220 & 4,0 & 3,8 & 0,2 & 4 \\
\hline Rešetari & 1.807 & 1.837 & -30 & 4.352 & 7,9 & 8,0 & $-0,1$ & 1 \\
\hline Sveti Martin na Muri & 1.794 & 1.770 & 24 & 2.541 & 4,6 & 4,5 & 0,1 & 3 \\
\hline Ivanska & 1.792 & 1.707 & 85 & 2.590 & 4,6 & 4,4 & 0,2 & 3 \\
\hline Draganić & 1.792 & 2.035 & -243 & 2.680 & 4,8 & 5,5 & $-0,7$ & 4 \\
\hline Sveta Marija & 1.781 & 1.581 & 200 & 2.178 & 3,9 & 3,4 & 0,4 & 5 \\
\hline Sveti Đurđ & 1.770 & 1.721 & 48 & 3.551 & 6,3 & 6,1 & 0,2 & 3 \\
\hline Bukovlje & 1.765 & 2.417 & -652 & 3.109 & 5,5 & 7,5 & $-2,0$ & 5 \\
\hline Kumrovec & 1.758 & 1.579 & 179 & 1.474 & 2,6 & 2,3 & 0,3 & 1 \\
\hline Babina Greda & 1.755 & 1.922 & -166 & 3.234 & 5,7 & 6,2 & $-0,5$ & 5 \\
\hline Velika & 1.743 & 1.991 & -248 & 5.146 & 9,0 & 10,2 & $-1,3$ & 5 \\
\hline Sveti Križ Začretje & 1.709 & 1.744 & -35 & 6.008 & 10,3 & 10,5 & $-0,2$ & 4 \\
\hline Klenovnik & 1.692 & 1.732 & -40 & 1.919 & 3,2 & 3,3 & $-0,1$ & 0 \\
\hline Nedelišće & 1.688 & 1.954 & -266 & 11.981 & 20,2 & 23,4 & $-3,2$ & 5 \\
\hline Donji Vidovec & 1.682 & 1.406 & 276 & 1.324 & 2,2 & 1,9 & 0,4 & 1 \\
\hline Goričan & 1.679 & 4.252 & -2.574 & 2.636 & 4,4 & 11,2 & $-6,8$ & 4 \\
\hline Breznički Hum & 1.678 & 1.577 & 102 & 1.281 & 2,2 & 2,0 & 0,1 & 2 \\
\hline Rasinja & 1.673 & 1.839 & -166 & 2.996 & 5,0 & 5,5 & $-0,5$ & 4 \\
\hline Sikirevci & 1.670 & 984 & 686 & 2.226 & 3,7 & 2,2 & 1,5 & 3 \\
\hline Čepin & 1.666 & 1.909 & -242 & 10.687 & 17,8 & 20,4 & $-2,6$ & 3 \\
\hline Dubrava & 1.657 & 1.845 & -189 & 4.827 & 8,0 & 8,9 & $-0,9$ & 4 \\
\hline Borovo & 1.650 & 1.459 & 191 & 4.559 & 7,5 & 6,7 & 0,9 & 3 \\
\hline Beretinec & 1.635 & 1.811 & -176 & 2.143 & 3,5 & 3,9 & $-0,4$ & 4 \\
\hline Slavonski Šamac & 1.631 & 1.548 & 83 & 1.891 & 3,1 & 2,9 & 0,2 & 2 \\
\hline Sokolovac & 1.630 & 1.643 & -13 & 3.168 & 5,2 & 5,2 & 0,0 & 5 \\
\hline Sveti Ivan Žabno & 1.618 & 1.427 & 190 & 4.900 & 7,9 & 7,0 & 0,9 & 5 \\
\hline Trpinja & 1.613 & 1.708 & -95 & 4.946 & 8,0 & 8,4 & $-0,5$ & 2 \\
\hline Trnovec Bartolovečki & 1.571 & 1.600 & -29 & 6.576 & 10,3 & 10,5 & $-0,2$ & 5 \\
\hline Bebrina & 1.551 & 1.802 & -251 & 3.041 & 4,7 & 5,5 & $-0,8$ & 4 \\
\hline Vidovec & 1.529 & 1.586 & -56 & 5.278 & 8,1 & 8,4 & $-0,3$ & 5 \\
\hline Kraljevec na Sutli & 1.527 & 1.598 & -71 & 1.590 & 2,4 & 2,5 & $-0,1$ & 4 \\
\hline Sveti Petar Orehovec & 1.525 & 1.381 & 144 & 4.317 & 6,6 & 6,0 & 0,6 & 4 \\
\hline Sračinec & 1.518 & 2.242 & -723 & 4.793 & 7,3 & 10,7 & $-3,5$ & 3 \\
\hline Mače & 1.518 & 1.559 & -41 & 2.393 & 3,6 & 3,7 & $-0,1$ & 5 \\
\hline Vratišinec & 1.483 & 1.357 & 126 & 1.876 & 2,8 & 2,5 & 0,2 & 5 \\
\hline Krašić & 1.460 & 1.780 & -320 & 2.437 & 3,6 & 4,3 & $-0,8$ & 3 \\
\hline Štitar & 1.455 & 1.100 & 356 & 1.870 & 2,7 & 2,1 & 0,7 & 4 \\
\hline Bedekovčina & 1.426 & 1.603 & -177 & 7.741 & 11,0 & 12,4 & $-1,4$ & 5 \\
\hline Petrijanec & 1.398 & 1.476 & -78 & 4.770 & 6,7 & 7,0 & $-0,4$ & 1 \\
\hline
\end{tabular}


Po stanovniku, u kn

Ukupno, u mil. kn

\begin{tabular}{|c|c|c|c|c|c|c|c|c|}
\hline & & 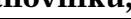 & & & & 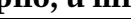 & & \\
\hline Općina & Prihodi & Rashodi & $\begin{array}{c}\text { Suficit } \\
\text { ili } \\
\text { deficit }\end{array}$ & $\begin{array}{c}\text { Broj } \\
\text { stanovni- } \\
\text { ka } 2016 .\end{array}$ & Prihodi & Rashodi & $\begin{array}{c}\text { Suficit } \\
\text { ili } \\
\text { deficit }\end{array}$ & $\begin{array}{c}\text { Transpa- } \\
\text { rentnost } \\
(0-5)\end{array}$ \\
\hline Sveti Juraj na Bregu & 1.303 & 1.302 & 1 & 5.096 & 6,6 & 6,6 & 0,0 & 3 \\
\hline Maruševec & 1.201 & 1.186 & 15 & 6.028 & 7,2 & 7,1 & 0,1 & 5 \\
\hline Pojezerje & 1.035 & 1.739 & -705 & 908 & 0,9 & 1,6 & $-0,6$ & 0 \\
\hline
\end{tabular}

Izvor: Autori na temelju: Ministarstva financija (20I8), DZS (2018), Ott i sur. (20I8).

Tabela 2.

Ostvarenje proračuna gradova u 2017.

Po stanovniku, u kn

Ukupno, u mil. kn

\begin{tabular}{|c|c|c|c|c|c|c|c|c|}
\hline Grad & Prihodi & Rashodi & $\begin{array}{c}\text { Suficit } \\
\text { ili } \\
\text { deficit }\end{array}$ & $\begin{array}{c}\text { Broj } \\
\text { stanovni- } \\
\text { ka } 2016 .\end{array}$ & Prihodi & Rashodi & $\begin{array}{c}\text { Suficit } \\
\text { ili } \\
\text { deficit }\end{array}$ & $\begin{array}{c}\text { Transpa- } \\
\text { rentnost } \\
(0-5)\end{array}$ \\
\hline Nin & 13.601 & 7.743 & 5.858 & 2.908 & 39,6 & 22,5 & 17,0 & 3 \\
\hline Novalja & 10.623 & 11.115 & -493 & 3.961 & 42,1 & 44,0 & $-2,0$ & 5 \\
\hline Novigrad & 9.824 & 9.200 & 625 & 4.481 & 44,0 & 41,2 & 2,8 & 5 \\
\hline Rovinj & 9.823 & 8.262 & 1.561 & 14.451 & 142,0 & 119,4 & 22,6 & 5 \\
\hline Umag & 9.277 & 9.337 & -59 & 13.828 & 128,3 & 129,1 & $-0,8$ & 5 \\
\hline Opatija & 9.168 & 11.666 & -2.498 & 11.145 & 102,2 & 130,0 & $-27,8$ & 5 \\
\hline Dubrovnik & 9.139 & 8.375 & 764 & 43.950 & 401,7 & 368,1 & 33,6 & 5 \\
\hline Hvar & 9.041 & 9.365 & -324 & 4.468 & 40,4 & 41,8 & $-1,4$ & 4 \\
\hline Poreč & 8.824 & 10.585 & -1.760 & 17.127 & 151,1 & 181,3 & $-30,2$ & 4 \\
\hline Cres & 8.359 & 9.565 & -1.205 & 2.903 & 24,3 & 27,8 & $-3,5$ & 5 \\
\hline Mali Lošinj & 8.295 & 7.808 & 487 & 8.115 & 67,3 & 63,4 & 4,0 & 4 \\
\hline Krk & 8.292 & 7.895 & 397 & 6.748 & 56,0 & 53,3 & 2,7 & 5 \\
\hline Zagreb & 8.177 & 8.647 & -470 & 803.647 & $6.571,6$ & $6.949,5$ & $-377,9$ & 5 \\
\hline Vis & 7.737 & 8.224 & -487 & 2.028 & 15,7 & 16,7 & $-1,0$ & 4 \\
\hline Crikvenica & 7.410 & 9.459 & -2.048 & 10.905 & 80,8 & 103,1 & $-22,3$ & 4 \\
\hline Novi Vinodolski & 7.271 & 6.954 & 317 & 4.925 & 35,8 & 34,2 & 1,6 & 4 \\
\hline Vodnjan & 7.045 & 7.334 & -289 & 6.353 & 44,8 & 46,6 & $-1,8$ & 5 \\
\hline Biograd na Moru & 6.755 & 7.725 & -970 & 5.731 & 38,7 & 44,3 & $-5,6$ & 3 \\
\hline Obrovac & 6.656 & 6.261 & 395 & 3.778 & 25,1 & 23,7 & 1,5 & 2 \\
\hline Vukovar & 6.354 & 5.380 & 974 & 24.219 & 153,9 & 130,3 & 23,6 & 4 \\
\hline Supetar & 6.273 & 5.608 & 665 & 4.382 & 27,5 & 24,6 & 2,9 & 4 \\
\hline Pula & 6.174 & 5.881 & 293 & 56.527 & 349,0 & 332,5 & 16,6 & 5 \\
\hline Pag & 6.167 & 6.359 & -192 & 3.700 & 22,8 & 23,5 & $-0,7$ & 4 \\
\hline Bakar & 6.167 & 6.586 & -419 & 8.173 & 50,4 & 53,8 & $-3,4$ & 5 \\
\hline Pazin & 6.029 & 6.062 & -33 & 8.383 & 50,5 & 50,8 & $-0,3$ & 5 \\
\hline Labin & 5.955 & 8.059 & -2.104 & 11.057 & 65,8 & 89,1 & $-23,3$ & 5 \\
\hline Senj & 5.673 & 5.854 & -181 & 6.561 & 37,2 & 38,4 & $-1,2$ & 2 \\
\hline Makarska & 5.602 & 5.555 & 47 & 14.317 & 80,2 & 79,5 & 0,7 & 5 \\
\hline Vodice & 5.572 & 6.313 & -741 & 9.289 & 51,8 & 58,6 & $-6,9$ & 5 \\
\hline Rijeka & 5.553 & 5.418 & 134 & 120.855 & 671,1 & 654,8 & 16,2 & 5 \\
\hline Omiš & 5.373 & 5.056 & 317 & 14.815 & 79,6 & 74,9 & 4,7 & 3 \\
\hline Buzet & 5.319 & 5.093 & 226 & 6.057 & 32,2 & 30,8 & 1,4 & 5 \\
\hline Vrlika & 5.228 & 5.173 & 55 & 1.879 & 9,8 & 9,7 & 0,1 & 5 \\
\hline Zaprešić & 5.207 & 6.036 & -829 & 25.181 & 131,1 & 152,0 & $-20,9$ & 4 \\
\hline Velika Gorica & 5.147 & 5.491 & -344 & 63.323 & 325,9 & 347,7 & $-21,8$ & 4 \\
\hline Korčula & 4.900 & 4.174 & 726 & 5.550 & 27,2 & 23,2 & 4,0 & 4 \\
\hline Zadar & 4.804 & 4.033 & 771 & 75.437 & 362,4 & 304,2 & 58,2 & 5 \\
\hline Varaždin & 4.780 & 4.252 & 529 & 46.294 & 221,3 & 196,8 & 24,5 & 4 \\
\hline Rab & 4.778 & 4.543 & 235 & 8.027 & 38,4 & 36,5 & 1,9 & 5 \\
\hline Slunj & 4.709 & 3.260 & 1.449 & 4.361 & 20,5 & 14,2 & 6,3 & 4 \\
\hline Samobor & 4.705 & 4.719 & -14 & 37.598 & 176,9 & 177,4 & $-0,5$ & 4 \\
\hline Opuzen & 4.658 & 2.457 & 2.201 & 3.164 & 14,7 & 7,8 & 7,0 & 4 \\
\hline Buje & 4.654 & 4.798 & -144 & 5.039 & 23,5 & 24,2 & $-0,7$ & 5 \\
\hline Split & 4.594 & 3.846 & 748 & 172.362 & 791,8 & 662,9 & 128,9 & 5 \\
\hline Sveta Nedelja & 4.590 & 4.022 & 569 & 18.298 & 84,0 & 73,6 & 10,4 & 4 \\
\hline Kastav & 4.588 & 4.043 & 545 & 10.666 & 48,9 & 43,1 & 5,8 & 5 \\
\hline
\end{tabular}

I4 NEWSLETTER II6 | K. OTT i sur. | Ostvarenje proračuna općina, gradova i županija u 20I7. | Institut za javne financije 
Po stanovniku, u kn

Ukupno, u mil. kn

\begin{tabular}{|c|c|c|c|c|c|c|c|c|}
\hline Grad & Prihodi & Rashodi & $\begin{array}{c}\text { Suficit } \\
\text { ili } \\
\text { deficit }\end{array}$ & $\begin{array}{c}\text { Broj } \\
\text { stanovni- } \\
\text { ka 20I6. }\end{array}$ & Prihodi & Rashodi & $\begin{array}{c}\text { Suficit } \\
\text { ili } \\
\text { deficit }\end{array}$ & $\begin{array}{c}\text { Transpa- } \\
\text { rentnost } \\
(o-5)\end{array}$ \\
\hline Gospić & 4.568 & 4.592 & -24 & 12.067 & 55,1 & 55,4 & $-0,3$ & 3 \\
\hline Trogir & 4.499 & 4.480 & 20 & 13.142 & 59,1 & 58,9 & 0,3 & 4 \\
\hline Stari Grad & 4.309 & 4.922 & -613 & 2.866 & 12,3 & 14,1 & $-1,8$ & 4 \\
\hline Delnice & 4.251 & 4.027 & 224 & 5.586 & 23,7 & 22,5 & 1,3 & 5 \\
\hline Čakovec & 4.098 & 3.771 & 327 & 27.801 & 113,9 & 104,8 & 9,1 & 5 \\
\hline Komiža & 4.038 & 4.203 & -166 & 1.500 & 6,1 & 6,3 & $-0,2$ & 3 \\
\hline Sisak & 3.985 & 4.692 & -707 & 44.411 & 177,0 & 208,4 & $-31,4$ & 5 \\
\hline Karlovac & 3.980 & 4.043 & -62 & 52.488 & 208,9 & 212,2 & $-3,3$ & 5 \\
\hline Pakrac & 3.948 & 3.906 & 43 & 7.263 & 28,7 & 28,4 & 0,3 & 3 \\
\hline Ozalj & 3.944 & 3.867 & 77 & 6.316 & 24,9 & 24,4 & 0,5 & 5 \\
\hline Šibenik & 3.877 & 3.881 & -4 & 45.008 & 174,5 & 174,7 & $-0,2$ & 4 \\
\hline Đurđevac & 3.840 & 4.780 & -940 & 7.903 & 30,3 & 37,8 & $-7,4$ & 2 \\
\hline Zabok & 3.836 & 3.933 & -96 & 8.840 & 33,9 & 34,8 & $-0,9$ & 5 \\
\hline Koprivnica & 3.835 & 4.117 & -283 & 30.466 & 116,8 & 125,4 & $-8,6$ & 5 \\
\hline Skradin & 3.800 & 2.821 & 979 & 3.348 & 12,7 & 9,4 & 3,3 & 3 \\
\hline Ivanić-Grad & 3.760 & 4.152 & -391 & 13.858 & 52,1 & 57,5 & $-5,4$ & 4 \\
\hline Osijek & 3.708 & 3.512 & 196 & 104.638 & 387,9 & 367,5 & 20,5 & 5 \\
\hline Kraljevica & 3.666 & 3.683 & -17 & 4.485 & 16,4 & 16,5 & $-0,1$ & 4 \\
\hline Novska & 3.641 & 3.578 & 63 & 12.453 & 45,3 & 44,6 & 0,8 & 5 \\
\hline Nova Gradiška & 3.598 & 3.503 & 95 & 13.133 & 47,3 & 46,0 & 1,2 & 4 \\
\hline Prelog & 3.580 & 3.631 & -51 & 7.671 & 27,5 & 27,9 & $-0,4$ & 5 \\
\hline Solin & 3.570 & 3.560 & 11 & 25.892 & 92,4 & 92,2 & 0,3 & 3 \\
\hline Drniš & 3.540 & 3.398 & 142 & 6.616 & 23,4 & 22,5 & 0,9 & 4 \\
\hline Ploče & 3.468 & 3.185 & 283 & 9.141 & 31,7 & 29,1 & 2,6 & 4 \\
\hline Kutina & 3.450 & 3.441 & 10 & 21.427 & 73,9 & 73,7 & 0,2 & 4 \\
\hline Vrbovsko & 3.417 & 3.498 & -82 & 4.441 & 15,2 & 15,5 & $-0,4$ & 5 \\
\hline Glina & 3.392 & 3.684 & -293 & 7.408 & 25,1 & 27,3 & $-2,2$ & 4 \\
\hline Beli Manastir & 3.371 & 3.967 & -595 & 8.970 & 30,2 & 35,6 & $-5,3$ & 2 \\
\hline Lipik & 3.313 & 3.670 & -356 & 5.496 & 18,2 & 20,2 & $-2,0$ & 3 \\
\hline Čabar & 3.269 & 3.338 & -69 & 3.388 & 11,1 & 11,3 & $-0,2$ & 2 \\
\hline Čazma & 3.261 & 3.098 & 163 & 7.545 & 24,6 & 23,4 & 1,2 & 3 \\
\hline Grubišno Polje & 3.198 & 3.473 & -275 & 5.745 & 18,4 & 20,0 & $-1,6$ & 5 \\
\hline Hrvatska Kostajnica & 3.188 & 2.943 & 245 & 2.197 & 7,0 & 6,5 & 0,5 & 4 \\
\hline Otočac & 3.169 & 3.004 & 165 & 9.144 & 29,0 & 27,5 & 1,5 & 3 \\
\hline Mursko Središće & 3.124 & 3.093 & 31 & 6.193 & 19,3 & 19,2 & 0,2 & 3 \\
\hline Knin & 3.108 & 2.570 & 538 & 12.594 & 39,1 & 32,4 & 6,8 & 4 \\
\hline Virovitica & 3.100 & 3.388 & -289 & 20.556 & 63,7 & 69,7 & $-5,9$ & 4 \\
\hline Petrinja & 3.052 & 3.227 & -176 & 22.128 & 67,5 & 71,4 & $-3,9$ & 2 \\
\hline Belišće & 2.999 & 3.670 & -671 & 10.150 & 30,4 & 37,3 & $-6,8$ & 3 \\
\hline Vrgorac & 2.936 & 2.909 & 28 & 5.754 & 16,9 & 16,7 & 0,2 & 1 \\
\hline Jastrebarsko & 2.924 & 3.198 & -273 & 15.293 & 44,7 & 48,9 & $-4,2$ & 5 \\
\hline Bjelovar & 2.920 & 2.910 & 10 & 38.783 & 113,2 & 112,9 & 0,4 & 4 \\
\hline Županja & 2.854 & 2.728 & 126 & 10.644 & 30,4 & 29,0 & 1,3 & 3 \\
\hline Ludbreg & 2.843 & 2.903 & -61 & 8.801 & 25,0 & 25,6 & $-0,5$ & 5 \\
\hline Imotski & 2.834 & 2.467 & 367 & 10.298 & 29,2 & 25,4 & 3,8 & 2 \\
\hline Otok (Vinkovci) & 2.813 & 3.212 & -399 & 5.633 & 15,8 & 18,1 & $-2,2$ & 2 \\
\hline Popovača & 2.808 & 2.907 & -99 & 11.367 & 31,9 & 33,0 & $-1,1$ & 4 \\
\hline Ogulin & 2.782 & 2.582 & 200 & 13.182 & 36,7 & 34,0 & 2,6 & 5 \\
\hline Krapina & 2.768 & 3.014 & -247 & 12.132 & 33,6 & 36,6 & $-3,0$ & 5 \\
\hline Orahovica & 2.733 & 4.647 & -1.914 & 4.844 & 13,2 & 22,5 & $-9,3$ & 5 \\
\hline Požega & 2.725 & 3.301 & -577 & 24.522 & 66,8 & 81,0 & $-14,1$ & 5 \\
\hline Slavonski Brod & 2.708 & 2.689 & 19 & 55.825 & 151,2 & 150,1 & 1,1 & 5 \\
\hline Benkovac & 2.647 & 2.853 & -206 & 9.879 & 26,1 & 28,2 & $-2,0$ & 5 \\
\hline Kaštela & 2.581 & 2.777 & -195 & 40.658 & 105,0 & 112,9 & $-7,9$ & 5 \\
\hline Garešnica & 2.575 & 2.647 & -72 & 9.449 & 24,3 & 25,0 & $-0,7$ & 4 \\
\hline Slatina & 2.564 & 2.464 & 101 & 12.697 & 32,6 & 31,3 & 1,3 & 3 \\
\hline Vinkovci & 2.509 & 2.462 & 48 & 34.986 & 87,8 & 86,1 & 1,7 & 2 \\
\hline
\end{tabular}

NEWSLETTER iı6 | K. OTT i sur. | Ostvarenje proračuna općina, gradova i županija u 20I7. | Institut za javne financije I5 
Po stanovniku, u kn

Ukupno, u mil. kn

\begin{tabular}{|c|c|c|c|c|c|c|c|c|}
\hline Grad & Prihodi & Rashodi & $\begin{array}{c}\text { Suficit } \\
\text { ili } \\
\text { deficit }\end{array}$ & $\begin{array}{c}\text { Broj } \\
\text { stanovni- } \\
\text { ka } 2016 . \\
\end{array}$ & Prihodi & Rashodi & $\begin{array}{c}\text { Suficit } \\
\text { ili } \\
\text { deficit }\end{array}$ & $\begin{array}{l}\text { Transpa- } \\
\text { rentnost } \\
(0-5)\end{array}$ \\
\hline Daruvar & 2.403 & 2.243 & 160 & 10.839 & 26,0 & 24,3 & 1,7 & 4 \\
\hline Križevci & 2.400 & 2.189 & 212 & 20.303 & 48,7 & 44,4 & 4,3 & 4 \\
\hline Dugo Selo & 2.390 & 2.471 & -81 & 18.143 & 43,4 & 44,8 & $-1,5$ & 4 \\
\hline Ilok & 2.384 & 2.724 & -339 & 6.030 & 14,4 & 16,4 & $-2,0$ & 3 \\
\hline Đakovo & 2.355 & 2.164 & 191 & 26.433 & 62,2 & 57,2 & 5,0 & 4 \\
\hline Trilj & 2.319 & 3.026 & -707 & 8.540 & 19,8 & 25,8 & $-6,0$ & 1 \\
\hline Pleternica & 2.312 & 2.205 & 107 & 10.284 & 23,8 & 22,7 & 1,1 & 5 \\
\hline Klanjec & 2.246 & 2.219 & 27 & 2.738 & 6,1 & 6,1 & 0,1 & 5 \\
\hline Zlatar & 2.239 & 2.491 & -252 & 5.738 & 12,8 & 14,3 & $-1,4$ & 5 \\
\hline Valpovo & 2.234 & 2.560 & -326 & 10.937 & 24,4 & 28,0 & $-3,6$ & 2 \\
\hline Donja Stubica & 2.222 & 2.411 & -189 & 5.809 & 12,9 & 14,0 & $-1,1$ & 5 \\
\hline Našice & 2.201 & 2.237 & -36 & 15.798 & 34,8 & 35,3 & $-0,6$ & 4 \\
\hline Vrbovec & 2.164 & 2.179 & -15 & 14.341 & 31,0 & 31,2 & $-0,2$ & 4 \\
\hline Oroslavje & 2.137 & 2.254 & -116 & 6.074 & 13,0 & 13,7 & $-0,7$ & 5 \\
\hline Duga Resa & 2.117 & 2.054 & 64 & 10.776 & 22,8 & 22,1 & 0,7 & 5 \\
\hline Sveti Ivan Zelina & 1.949 & 2.018 & -69 & 15.190 & 29,6 & 30,7 & $-1,1$ & 4 \\
\hline Varaždinske Toplice & 1.894 & 1.484 & 410 & 6.020 & 11,4 & 8,9 & 2,5 & 5 \\
\hline Pregrada & 1.887 & 1.799 & 88 & 6.226 & 11,7 & 11,2 & 0,5 & 5 \\
\hline Kutjevo & 1.849 & 1.855 & -6 & 5.566 & 10,3 & 10,3 & 0,0 & 2 \\
\hline Ivanec & 1.848 & 1.905 & -57 & 13.326 & 24,6 & 25,4 & $-0,8$ & 5 \\
\hline Sinj & 1.829 & 1.962 & -133 & 24.476 & 44,8 & 48,0 & $-3,3$ & 2 \\
\hline Metković & 1.821 & 1.526 & 295 & 16.371 & 29,8 & 25,0 & 4,8 & 3 \\
\hline Donji Miholjac & 1.711 & 1.561 & 150 & 8.910 & 15,2 & 13,9 & 1,3 & 3 \\
\hline Novi Marof & 1.647 & 1.599 & 48 & 12.618 & 20,8 & 20,2 & 0,6 & 3 \\
\hline Lepoglava & 1.548 & 1.787 & -239 & 7.785 & 12,1 & 13,9 & $-1,9$ & 4 \\
\hline
\end{tabular}

Izvor: Autori na temelju: Ministarstva financija (2018), DZS (2018), Ott i sur. (2018).

Tabela 3.

Ostvarenje proračuna županija u 2017.

Po stanovniku, u kn

Ukupno, u mil. kn

\begin{tabular}{|c|c|c|c|c|c|c|c|c|}
\hline Županija & Prihodi & Rashodi & $\begin{array}{c}\text { Suficit } \\
\text { ili } \\
\text { deficit }\end{array}$ & $\begin{array}{c}\text { Broj } \\
\text { stanovni- } \\
\text { ka } 2016 .\end{array}$ & Prihodi & Rashodi & $\begin{array}{c}\text { Suficit } \\
\text { ili } \\
\text { deficit }\end{array}$ & $\begin{array}{c}\text { Transpa- } \\
\text { rentnost } \\
(0-5)\end{array}$ \\
\hline Ličko-senjska & 2.750 & 2.747 & 3 & 46.485 & 127,8 & 127,7 & 0,1 & 5 \\
\hline Požeško-slavonska & 1.609 & 1.532 & 77 & 70.937 & 114,1 & 108,7 & 5,5 & 5 \\
\hline $\begin{array}{l}\text { Dubrovačko- } \\
\text { neretvanska }\end{array}$ & 1.484 & 1.437 & 47 & 121.671 & 180,6 & 174,9 & 5,7 & 5 \\
\hline Sisačko-moslavačka & 1.446 & 1.386 & 60 & 155.251 & 224,5 & 215,2 & 9,3 & 5 \\
\hline Virovitičko-podravska & 1.437 & 1.415 & 22 & 78.239 & 112,4 & 110,7 & 1,7 & 4 \\
\hline Zadarska & 1.332 & 1.217 & 115 & 169.306 & 225,5 & 206,1 & 19,4 & 5 \\
\hline Istarska & 1.307 & 1.220 & 86 & 208.109 & 271,9 & 254,0 & 18,0 & 5 \\
\hline Vukovarsko-srijemska & 1.290 & 1.280 & 9 & 163.324 & 210,6 & 209,1 & 1,5 & 4 \\
\hline Koprivničko-križevačka & 1.283 & 1.274 & 9 & 110.129 & 141,3 & 140,3 & 1,0 & 4 \\
\hline Međimurska & 1.282 & 1.219 & 63 & 111.669 & 143,2 & 136,2 & 7,0 & 5 \\
\hline Šibensko-kninska & 1.274 & 1.359 & -85 & 102.238 & 130,3 & 139,0 & $-8,7$ & 5 \\
\hline Varaždinska & 1.243 & 1.254 & -11 & 169.805 & 211,1 & 213,0 & $-1,9$ & 5 \\
\hline Krapinsko-zagorska & 1.229 & 1.183 & 46 & 127.060 & 156,2 & 150,3 & 5,9 & 5 \\
\hline Karlovačka & 1.201 & 1.133 & 68 & 119.464 & 143,5 & 135,4 & 8,1 & 5 \\
\hline Primorsko-goranska & 1.109 & 1.091 & 18 & 288.328 & 319,7 & 314,4 & 5,2 & 5 \\
\hline Brodsko-posavska & 1.100 & 1.163 & -63 & 146.288 & 160,9 & 170,1 & $-9,1$ & 5 \\
\hline Bjelovarsko-bilogorska & 1.035 & 969 & 67 & 110.841 & 114,7 & 107,4 & 7,4 & 5 \\
\hline Splitsko-dalmatinska & 1.017 & 983 & 33 & 451.226 & 458,7 & 443,7 & 15,0 & 5 \\
\hline Osječko-baranjska & 986 & 1.045 & -60 & 287.124 & 283,0 & 300,1 & $-17,1$ & 5 \\
\hline Zagrebačka & 960 & 938 & 22 & 313.072 & 300,5 & 293,6 & 6,9 & 5 \\
\hline
\end{tabular}

Izvor: Autori na temelju: Ministarstva financija (20I8), DZS (20I8), Ott i sur. (20I8). 